\title{
Biogenic production of DMSP and its degradation to DMS - their roles in the global sulfur cycle
}

\author{
Xiao-Hua Zhang ${ }^{1,2 *}$, Ji Liu ${ }^{1}$, Jingli Liu ${ }^{1}$, Gui-Peng Yang ${ }^{2,3}$, Chun-Xu Xue ${ }^{1}$, Andrew R. \\ J. Curson ${ }^{4}, \&$ Jonathan D. Todd ${ }^{4}$ \\ ${ }^{I}$ MOE Key Laboratory of Marine Genetics and Breeding, College of Marine Life Sciences, Ocean \\ University of China, Qingdao 266003, China; \\ ${ }^{2}$ Laboratory for Marine Ecology and Environmental Science, Qingdao National Laboratory for \\ Marine Science and Technology, Qingdao 266237, China; \\ ${ }^{3}$ College of Chemistry and Chemical Engineering, Ocean University of China, Qingdao 266071, \\ China; \\ ${ }^{4}$ School of Biological Sciences, University of East Anglia, Norwich NR4 7TJ, UK \\ *Corresponding author: \\ Tel/Fax: +86-532-82032767; Email: xhzhang@ouc.edu.cn
}

Running title: DMSP biosynthesis and catabolism

\begin{abstract}
Dimethyl sulfide (DMS) is the most abundant form of volatile sulfur in Earth's oceans, and is mainly produced by the enzymatic clevage of dimethylsulfoniopropionate (DMSP). DMS and DMSP play important roles in driving the global sulfur cycle and may affect climate. DMSP is proposed to serve as an osmolyte, a grazing deterrent, a signaling molecule, an antioxidant, a cryoprotectant and/or as a sink for excess sulfur. It was long believed that only marine eukaryotes such as phytoplankton produce DMSP. However, we recently discovered that marine heterotrophic bacteria can also produce DMSP, making them a potentially important source of DMSP. At present, one prokaryotic and two eukaryotic DMSP synthesis enzymes have been identified. Marine heterotrophic bacteria are likely the major degraders of DMSP, using two known pathways: demethylation and cleavage. Many phytoplankton and some fungi can also cleave DMSP. So far seven different prokaryotic and one eukaryotic DMSP lyases have been identified. This review describes the global distribution pattern of DMSP and DMS, the known genes for biosynthesis and cleavage of DMSP, and the physiological and ecological functions of these important organosulfur molecules, which will improve understanding of the mechanisms of DMSP and DMS production and their roles in the environment.
\end{abstract}

Key words: marine microorganism; dimethylsulfoniopropionate (DMSP); dimethyl sulfide (DMS); DMSP biosynthesis; DMSP cleavage 


\section{INTRODUCTION}

The biogenic trace gas dimethyl sulfide (DMS) is the dominant natural source of volatile organic sulfur compounds emitted into the atmosphere from the marine environment (Charlson et al., 1987; Andreae, 1990; Simó, 2001; Stefels et al., 2007). The amount of sulfur (in the form of DMS) transferred from ocean to atmosphere is approximately 13-37 Tg annually (Ksionzek et al., 2016).

DMS emissions not only balance the global sulfur budget, but may also impact Earth's climate through its oxidation products in the atmosphere (Figure 1). When DMS diffuses into the atmosphere, it can be rapidly oxidised by $\mathrm{OH}$ (during the day) and $\mathrm{NO}_{3}$ (at night) radicals to form various sulfur-containing products, such as sulfur dioxide $\left(\mathrm{SO}_{2}\right)$, methanesulfonic acid (MSA) and non-sea-salt sulfate (nss- $\mathrm{SO}_{4}{ }^{2-}$ ) (Andreae et al., 1985; Boucher and Pham, 2002). Sulfate produced by this process not only increases the natural acidity of atmospheric deposition, but also contributes to cloud condensation nuclei (CCN) in remote marine environments (Quinn and Bates 2011; Charlson et al. 1987). Changes in CCN concentration affect the cloud droplet number and concentration, which influences cloud albedo and potentially affects global temperature (Charlson et al., 1987). However, the contradictory view has also been proposed that a DMS biological control over CCN probably does not exist and the bioregulation of DMS on climate has been exaggerated (Quinn and Bates, 2011).

The main precursor of DMS is dimethylsulfoniopropionate (DMSP), an organic sulfur compound that is produced in prodigious amounts (2.0 petagrams sulfur annually, worldwide) by many marine organisms, thought mainly to be including marine phytoplankton (Figure 1; Keller et al., 1989; Stefels et al., 2007; Ksionzek et al. 2016). Upon the release of intracellular DMSP into the environment, it can be taken up by a wide range of microorganisms (Malmstrom et al., 2004; Vila et al., 2004; Raina et al., 2017) and catabolised as a source of carbon, reduced sulfur and/or energy (Reisch et al., 2013; Raina et al., 2009; Tripp et al., 2008). DMSP is cleaved to produce DMS and the co-products acrylate or 3-hydroxypropionate (3-HP) by intracellular algal or bacterial DMSP-lyase enzymes (Figure 1; Curson et al., 2011; Johnston et al., 2016). It is thought that only a minor fraction of dissolved DMSP, varying between $2 \%$ and $21 \%$, is enzymatically cleaved to liberate DMS (Kiene and Linn, 2000). The majority of DMSP is likely demethylated by bacterial activity, and does not lead to the formation of DMS, but instead can lead to the generation of the trace gas methanethiol (MeSH; Kiene and Linn, 2000; Yoch, 2002; Howard et al., 2006).

In all known DMSP synthesis pathways, DMSP is synthesised from the amino acid L-methionine (Met), and is likely more abundant in marine than terrestrial environments because of the high concentration of sulfate in seawater (Stefels, 2000). 
The marine organisms that make DMSP include single-celled phytoplankton (such as dinoflagellates, diatoms and coccolithophores) (Keller et al., 1989; Curson et al., 2018; Kageyama et al., 2018), some red and green algae (Challenger and Simpson, 1948; Greene, 1962), a few angiosperms (Otte et al., 2004), as well as some corals (Raina et al., 2013). More recently, it has been found that marine heterotrophic bacteria can also make DMSP, making them a potentially important source of marine DMSP (Curson et al., 2017).

DMSP is proposed to serve numerous physiological functions in organisms that accumulate it under different environmental conditions (Otte et al., 2004). Its specific function may vary in different organisms, perhaps based on where DMSP is localised in the cell (Trossat et al., 1996, 1998). For example, DMSP detected in the chloroplasts of the angiosperm Wollastonia was considered to contribute significantly to chloroplast osmoregulation and may protect photosynthetic processes from stress (Trossat et al., 1998). Furthermore, DMSP also acts as a carbon, sulfur and/or energy store and its synthesis may prevent the depletion of important nitrogen precursors during periods of nitrogen limitation (Stefels et al., 2000).

In this Review, we focus on the distribution pattern of DMSP and DMS in the marine environment, the relative contributions of marine phytoplankton and bacteria to the production of DMSP and its degradation to DMS, the physiological function of DMSP and DMS and their roles in the global sulfur cycle.

\section{DISTRIBUTION OF DMSP AND DMS IN THE MARINE ENVIRONMENT}

DMSP is ubiquitous in the euphotic layers of the marine system, with a wide variation in concentrations ranging from low nanomolar to several micromolar concentrations (Table 1). DMS is produced mainly from the cleavage of DMSP, but can also be produced from DMSP-independent sources (Carrión et al., 2015, 2017). To a certain extent, the distributions of DMSP and DMS show similar variation patterns in the surface ocean. Here we summarise many of the surveys of global DMSP and DMS distribution in last 30 years from 1988 to 2018 (Table 1). The concentration of total DMSP (DMSPt) was always less than $1.78 \mu \mathrm{M}$ in seawater. The majority of DMSP is found within microorganisms, termed 'particulate DMSP' (DMSPp; $\leq 1.74 \mu \mathrm{M}$ ), whilst the available DMSP, 'dissolved DMSP' (DMSPd), concentrations are lower at $\leq 275$ nM.

\section{Spatial characteristics}

On a global scale, in polar and subpolar regions, higher DMS and DMSP concentrations are always observed (Table 1). In Arctic Ocean (e.g., Northeast Atlantic and Norwegian and Greenland Seas) surface seawater, DMS concentrations were observed up to $93.8 \mathrm{nM}$, while DMSPp and DMSPd were up to $282.4 \mathrm{nM}$ and $199 \mathrm{nM}$, 
respectively, likely due to the phytoplankton blooms arising during seasonal sea ice melting (Malin et al., 1993; Li et al., 2015). Relatively high DMS and DMSP concentrations also occurred in the Ross Sea (Rellinger et al., 2009), the West Antarctic Penisula (Stefels et al., 2018) and Canadian subarctic and arctic marine water (Jarníková et al., 2018) as shown in Table 1.

In high-latitude and temperate regions, high DMS and DMSP concentrations, socalled "hotspots", coincide with the high primary productivity ocean areas. In the East China continental sea, the average DMS, DMSPd and DMSPp concentrations in summer are observed at $5.3 \mathrm{nM}, 5.2 \mathrm{nM}$ and $27.1 \mathrm{nM}$, respectively (Zhang et al., 2014). High concentrations of DMSP are also reported in the Gulf of Maine (Matrai et al., 1993) and Gulf of Saint Lawrence (Cantin et al., 1996). In addition, a study of the Belgian coastal zone showed relatively high phytoplankton biomass levels occurred in the coastal upwelling areas because of the vertical supply of nutrients, and this was accompanied by high DMS and DMSP concentrations, with concentrations of DMSPt up to $1.78 \mu \mathrm{M}$ and DMS up to $270 \mathrm{nM}$ (Speeckaert et al., 2018). High concentrations of DMS and DMSPp are also reported in waters off the western coast of Ireland, up to $42 \mathrm{nM}$ and 50 - $635 \mathrm{nM}$ respectively (Locarnini et al., 1998). The tropical oceans show moderate and relatively constant DMS concentrations throughout the year (Bates and Quinn, 1997).

The vertical distribution of DMS and DMSP in seawater generally exhibit decreasing trends from the surface waters to the deeper waters (Table 1). Maximum DMS and DMSP concentrations are usually found in surface seawater or in seawater < $100 \mathrm{~m}$ below the surface, but are reduced in the marine euphotic zone. Since phytoplankton are widely recognised as the major producers of DMSP in the marine environment, it is not surprising that vertical distribution patterns of DMSP and DMS resemble those of phytoplankton.

\section{Seasonal cycle pattern}

In both hemispheres, DMSP and DMS concentrations exhibit similar seasonal cycle patterns in relation to changes in temperature and light. That is, the DMS and DMSP concentrations rise in spring and usually peak in late summer, and then decrease through autumn and winter. These temporal distribution variations are particularly apparent in middle-high latitude ocean regions, such as the North Pacific Ocean where the average DMS concentration reaches the maximum $(>5 \mathrm{nM})$ in the summer and drops to the minimum $(<1 \mathrm{nM})$ in the winter (Aranami and Tsunogai, 2004). In the Yellow-East China Sea, the concentration of DMSP was lowest (6.5-18.0 nM) during winter, and highest in summer (7.6-234.9 nM), and slightly higher in autumn (7.4-91.0 $\mathrm{nM}$ ) than in spring (5.5-73.7 nM) (Yang et al., 2006, 2011, 2012; Zhang et al., 2014, 2017). Moving towards the equator, this seasonal cycle pattern gets less pronounced 
and even disappears, consistent with the associated reduction in seasonality meaning decreasing variation in temperature or day length. In the tropical oceans around the equator, the average concentrations of DMS and DMSP are reasonably constant throughout the year.

Diurnal cycles of DMS and DMSP concentrations are also present. Song et al. (2014) reported DMSP concentrations in off-shore areas were higher in the daytime than at night, and the DMS concentration peaked in the afternoon and reached the minimum in the early morning.

\section{Effect of environmental factors on DMSP and DMS distribution}

The distribution of DMSP and DMS in seawater is affected by various physical, chemical and biological factors. In the Norwegian Sea and the Greenland Sea, chlorophyll $a$ concentration (indicator of phytoplankton biomass) was shown to be the most significant impact factor in DMSP production, followed by seawater temperature and salinity (Li et al., 2015). In marginal seas, anthropogenic factors, such as atmospheric pollution, may play important roles in the production of DMSP and DMS (Yang et al., 2015). In addition, nitrogen availability is well known as a major influencing factor in increasing intracellular levels of DMSP in marine phytoplankton (Keller et al., 1996; Sunda et al., 2007; Curson et al 2018). Nutrients like silicate could indirectly affect DMSP production through a significant effect on the growth of larger nanoplankton (Zhai et al., 2018). Solar radiation is also well known as an important driver of DMS dynamics in the ocean (Vallina and Simó, 2007). Biologically, as the driving force on DMSP degradation, the biomass and composition of bacteria in the marine environment have vital influence on DMS production. It is possible that all these factors, such as nutrient levels and solar radiation, may affect phytoplankton biomass, which are the direct factors affecting DMSP and DMS concentrations.

The DMS and DMSP temporal cycle pattern is usually associated with the biomass of phytoplankton, particularly the high DMSP-producing taxa, e.g., dinoflagellates and prymnesiophytes (Keller, 1989). Higher phytoplankton biomass and biological activities are found during the warmer and more illuminated seasons, which leads to more DMSP and more of its bio-degradation product, DMS. Townsend and Keller (1996) found that concentrations of DMSPp were related more to the presence of specific phytoplankton species rather than to overall phytoplankton biomass. The study of Scarratt et al (2002) in the northwest Atlantic also showed statistically significant correlations between the abundance of dinoflagellates and prymnesiophytes and the concentrations of DMS(P). In the region with the highest DMS(P) concentrations, the phytoplankton assemblage was dominated by Chrysochromulina spp. (prymnesiophyte) and Gyrodinium flagellare (dinoflagellate) whose abundance showed a marked correlation with total DMSPp as well as the 2 to $11 \mu \mathrm{m}$ size fraction of DMSP. In 
addition, Archer et al. (2009) discovered a taxonomic succession of high DMSPproducing phytoplankton is apparent in the seasonal pattern of DMSPt concentrations. Peridinin and DMSPt concentrations showed similar seasonal trends, which illustrates the substantial contribution by the dinoflagellate taxa to DMSP production. However, in low-latitude temperate and northern subtropical areas, DMS exhibits high levels in the summer, when phytoplankton biomass is low, and this has been coined the "DMS summer paradox" (Simó and Pedrós-Alió, 1999). The possible reason(s) might be both or either: 1) taxonomic succession from minor to major DMSP-producing phytoplankton as previously proposed (Simó and Pedrós-Alió, 1999); 2) blooming of DMSP-producing bacterial taxa which were found in our recently discovery (Curson et al., 2017).

\section{BIOSYNTHESIS OF DMSP}

Biosynthesis of DMSP has been identified in some plants, macroalgae, phytoplankton, corals (Reed, 1983; Keller et al., 1989; Paquet et al., 1994; Hanson et al., 1994; Kocsis et al., 1998; Otte et al., 2004; Raina et al., 2013; Ausma et al., 2017), and most recently also discovered in many marine bacteria (Table 2; Curson et al., 2017). Thus, DMSP is present in all marine ecosystems and can be utilised not only by the producing organisms, but also by other species that live in the same habitats with the producers.

\section{Biosynthesis of DMSP by marine eukaryotes}

DMSP was first identified in 1948 in the red alga Polysiphonia (Challenger \& Simpson, 1948). The main DMSP producers are widely recognised to be marine phytoplankton, and strains in the classes of Dinophyceae (dinoflagellates) and Prymnesiophyceae (haptophytes) were recorded with high intracellular DMSP concentrations of up to $10^{2}-10^{3} \mathrm{mM}$ (Keller, 1989; Stefels, 2000). As well as these very high producers, DMSP biosynthesis has also been documented in other marine algae, e.g. diatoms (Lyon et al., 2011; Kettles et al., 2014), the green alga Ulva intestinalis (Gage et al., 1997), and some higher plants like sugarcane (Paquet et al., 1994) and the coastal angiosperms Spartina alterniflora (Kocsis et al., 1998) and Wollastonia biflora (Hanson et al., 1994). The green tide (Ulva bloom), which occurs annually in the summer in the Yellow Sea and East China Sea (Figure 2), always brings with it a tangy odour (DMS is one of the compounds contributing to the complex smell) during the algal decay process. Recently, DMSP biosynthesis was also reported in the kingdom of animalia with two corals species Acropora millepora and Acropora tenuis shown to produce DMSP (Raina et al., 2013). The occurrence of DMSP in corals was previously attributed to the DMSP-producing coral symbiont Symbiodinium, but investigations of algal-free juvenile corals clearly demonstrated a heat stress-dependent DMSP production by the marine invertebrates themselves (Raina et al., 2013). Orthologues of 
the eukaryotic DSYB DMSP biosynthesis gene present in the genome of the coral Acropora cervicornis were shown to encode a functional SAM-dependent methyltransferase, catalyzing the key enzymatic step in DMSP biosynthesis via the transamination pathway (Curson et al., 2018).

At present, it is known that DMSP synthesis in marine eukaryotes can occur through four different pathways, two methylation pathways in angiosperms (Hanson and Gage, 1996; Kocsis et al., 1998), a transamination pathway in diatoms, dinoflagellates, haptophytes, green algae and corals (Gage et al., 1997; Summers et al., 1998; Raina et al., 2013; Curson et al., 2018) and a decarboxylation pathway in one dinoflagellate (Uchida et al., 1996). Each of the proposed pathways for DMSP biosynthesis begins with methionine, although subsequent steps vary (Figure 3). Since the biosynthesis reactions and enzymes evolved are quite diverse, these different DMSP biosynthetic pathways must have evolved independently. However, it is unknown whether some taxonomically distinct organisms such as green algae, diatoms, dinoflagellates, haptophytes and corals use the same transamination pathway due to a horizontal gene transfer event or due to their evolving independently. DMSP production has been found to be species-specific, with some members of a genus producing it and others not, and can vary by three orders of magnitude within phytoplankton groups. The highest intracellular concentrations are typically reported in dinoflagellates and haptophytes and lower concentrations in diatoms (Table 2; Keller, 1989).

Although it has long been known that eukaryotic algae can produce DMSP, the lack of genomic sequences and molecular tools for studying marine eukaryotes meant that the functional genes have only recently been identified. Todd and colleagues, based on work in bacteria (see below), identified the DSYB gene, encoding a SAM-dependent methyltransferase, in many marine algae, including dinoflagellates, diatoms and coccolithophores, as well as in some corals. DSYB mediates the key step of the transamination pathway, transforming 4-methylthio-2-hydroxybutyrate (MTHB) to 4dimethylsulfonio-2-hydroxybutyrate (DMSHB; Table 2; Curson 2018). Takabe and colleagues have recently found the isozyme of DSYB in the diatom Thalassiosira pseudonana, named TpMMT (Table 2), encoded by the TpMT2 gene, which showed no significant homology with ratified DSYBs (Kageyama et al., 2018). DMSP synthesis genes involved in steps other than S-methylation have not been identified in any organisms so far.

\section{Biosynthesis of DMSP by marine bacteria}

Recently, DMSP biosynthesis was detected in Labrenzia aggregata LZB033 (Figure 4) and then also in several other marine Alphaproteobacteria, including Oceanicola batsensis HTCC2597, Pelagibaca bermudensis HTCC2601, Sediminimonas qiaohouensis DSM21189, Amorphus coralli DSM18348, Sagittula 
stellata E-37, L. aggregata IAM12614, and Thalassobaculum salexigens DSM19539 (Table 2; Curson et al., 2017). These bacteria synthesise DMSP through the transamination pathway, the same pathway used by many marine algae and some corals. Through screening an L. aggregata LZB033 genomic library for candidate DMSP biosynthesis genes, one gene $d s y B$, encoding a functional MTHB methyltransferase, was identified as the key gene in bacterial DMSP biosynthesis. The transfer of the $d s y B$ gene alone was sufficient to confer the ability to synthesise DMSP to the non-DMSP producing bacterium Rhizobium leguminosarum. This indicates that enzymes catalyzing the production of MTHB and the decarboxylation of DMSHB (see Fig 3) are not specific to DMSP production. The DsyB protein is a SAM-dependent methyltransferase and is encoded by the genomes of $\sim 100$ marine Alphaproteobacteria (E-value $\leq 5 \times 10^{-69}$ ). DsyB has relatively low similarity to the eukaryotic DSYB (Evalues $\leq 1 \times 10^{-30}$ ), but this low level of similarity was still sufficient to allow the subsequent identification of the eukaryotic $D S Y B$ gene described above. Environmental conditions known to affect DMSP production in marine phytoplankton, like increased salinity, nitrogen availability, and low temperatures, were also shown to upregulate the expression of the bacterial $d s y B$ gene, as well as the production of DMSP in $L$. aggregata LZB033 (Curson et al., 2017). The acquisition of $d s y B$ by some bacteria, and consequently the ability to synthesise DMSP, may confer a competitive advantage in the marine environment, where bacteria must contend with, for example, salinity and low nitrogen availability.

Phylogenetic analysis of eukaryotic DSYBs and alphaproteobacterial DsyBs showed that DSYB and DsyB sequences formed two distinct sister branches, but not all major algal groups have DSYB in their genomes (Curson et al., 2018). According to these facts, the authors concluded that eukaryotic DSYBs originated from bacterial DsyBs early in their evolution and they were obtained either: 1) through endosymbiosis of the mitochondrial ancestor, which led to alphaproteobacterial genes making up a significant proportion in eukaryotic genomes ( $\mathrm{Ku}$ et al., 2015), and then DSYB has been lost by some of the eukaryotes; or 2) more recently by multiple horizontal gene transfer (HGT) events (Curson et al., 2018).

\section{DMSP CLEAVAGE AND DMS PRODUCTION}

After biosynthesis, some of the produced DMSP can be cleaved to DMS and acrylate (or 3-HP) by the DMSP-producer themselves (Alcolombri et al., 2015; Curson et al., 2017). However, the vast majority of the DMSP is catabolised after it is released into the water column in the form of dissolved DMSP (DMSPd), and ultilised by other heterotrophic microorganisms, predominantly bacteria (Zubkov et al., 2001). The corresponding enzymes that catalyse DMSP cleavage are called DMSP lyases. They exist in both eukaryotes and bacteria. There is high biodiversity in the bacterial DMSP lyases, which belong to three distinct protein superfamilies, while the only known 
eukaryotic DMSP lyase Almal bears no resemblance to any of the bacterial 'Ddd' DMSP lyases (Table 3).

\section{Cleavage of DMSP by heterotrophic bacteria}

Although many marine phytoplankton degrade some of the DMSP that they produce (Stefels 2000), most of the microbial DMSP catabolism is thought to occur following its release into the dissolved organic matter pool caused by viral lysis, zooplankton grazing or senescence of the algal cells. Here, it is available for assimilation and degradation by free-living bacterioplankton or attached bacteria (Kiene et al., 2000).

Marine bacteria catabolise DMSP via two competing pathways, the demethylation pathway (accounting for the majority of DMSP degradation; Kiene et al 2000) and the cleavage pathway. The demethylation pathway can yield the reactive gas methanethiol (MeSH). The key enzyme DmdA, which belongs to the glycine cleavage T-protein (GcvT) superfamily, catalyses the first step in the DMSP demethylation pathway (Howard et al., 2006; Reisch et al., 2008), and genes for the subsequent steps of the DMSP demethylation pathway have also been fully elucidated by the Moran laboratory (Reisch et al., 2011a, 2011b, 2013; Moran et al., 2012). DMSP demethylation is a major biological control on DMS formation because it directly competes with the cleavage pathway. The cleavage pathway produces the climatically relevant volatile DMS via DMSP lysis or hydrolysis (González et al., 1999), which will be described in detail here.

Currently, seven bacterial DMSP cleavage genes $d d d D,-L,-P,-Q,-W,-Y$ and $-K$ have been identified, and the enzymes they encode mediate the cleavage of DMSP to DMS (Curson et al., 2011a; Johnston et al., 2016; Sun et al., 2016). These genes are found in various bacterial taxa. $d d d D$ is present in some Gammaproteobacteria, especially in Oceanospirillales and Pseudomonadales, and also in some other Proteobacteria, like Rhizobiales and Rhodobacterales (both Alphaproteobacteria) and Burkholderiales (Betaproteobacteria). $d d d L,-P,-Q$, and $-W$ are mainly found in the Rhodobacteraceae family of Alphaproteobacteria, with $d d d P$ also present in some eukaryotic fungi (Todd et al., 2009; Kirkwood et al., 2010). $d d d Y$ was identified in the betaproteobacterium Alcaligenes faecalis strain $\mathrm{M} 3 \mathrm{~A}$ and is found in other Proteobacteria, i.e. Gammaproteobacteria, Deltaproteobacteria and Epsilonproteobacteria (Curson et al., 2011b; Li et al., 2017). dddK was identified in Pelagibacter ubique HTCC1062, which belongs to the most abundant marine bacterial group - the SAR11 clade (Sun et al., 2016). Among these bacterial $d d d$ genes, $d d d P$ and $d d d Q$ are the two most abundant ones in marine metagenomes (Curson et al., 2018).

Interestingly, the protein products of these $d d d$ genes differ both in size and amino acid sequence and belong to distinct polypeptide families. DddL/Q/W/K/Y belong to the cupin superfamily (Table 3; Lei et al., 2018), and all catalyse DMSP lysis into DMS 
and acrylate. Biochemical and crystal structural studies revealed that DddQ, DddW, DddK and DddY all need metal cofactors, but that there is variability between which metal works best for each enzyme. For example, based on its crystal structure, DddQ from Ruegeria lacuscaerulensis ITI_1157 is bound to Zn (II), whereas the addition of exogenous Co (II) and Mn (II) can effectively enhance its activity (Li et al., 2014), while Brummet et al. (2016) proposed that the addition of Zn (II) can inhibit its activity and that $\mathrm{Fe}$ (III) is the appropriate co-factor. DddQ is clearly promiscuous in which metal co-factor it requires for activity. Based on biochemical studies, DddW from $R$. pomeroyi DSS-3 showed the highest enzyme activities with Fe (II) or Mn (II) as cofactors (Brummet et al., 2015); DddK from Pelagibacter can be activated by the presence of $\mathrm{Fe}$ (II) and $\mathrm{Ni}$ (II) (Schnicker et al., 2017). DddY from the gammaproteobacterium Acinetobacter bereziniae contains a catalytic domain with $\mathrm{Zn}$ (II) as cofactor (Li et al., 2017). Protein sequences of DddL show conserved active site residues with the other cupin DMSP lyases for metal cofactor binding, but enzymatic or structural biological studies on DddL have not been reported. DddP belongs to the M24B metallopeptidase family (Todd et al., 2009), and, like the cupin lyases, catalyses the cleavage of DMSP to DMS and acrylate. A study on the catalytic mechanism of DddP from $R$. lacuscaerulensis ITI_1157 revealed that mature DddP protein is a stable dimer and undergoes an Fe ion shift during the process of DMSP cleavage (Wang et al., 2015). DddD belongs to the class III CoA-transferase family (Todd et al., 2007), and is the only characterised Ddd that cleaves DMSP by hydrolysis and produces DMS and 3-HP or 3-HP-CoA (Todd et al., 2007; Alcolombri et al., 2014). Although, all the above Ddd enzymes can act on DMSP, liberating DMS, only DddD, DddY and DddL have high specific DMSP lyase activities (Kcat/Km; $318 \mathrm{M}^{-1} \mathrm{~s}^{-1}$ for DddD; $10^{5-6} \mathrm{M}^{-1} \mathrm{~s}^{-1}$ for DddY and $1.66 \times 10^{6} \mathrm{M}^{-1} \mathrm{~s}^{-1}$ for DddL), whilst the other Ddd lyases have much lower specific DMSP lyase activities (Alcolombri et al., 2014; Brummett et al., 2015; Lei et al., 2018). It should be noted though that much of the enzyme work is carried out with proteins overexpressed and purified from Escherichia coli and not from the natural host. What effects this has on the activity of the enzymes and their metal content is not always determined. The three-carbon moiety of DMSP, transformed to acrylate or 3-HP during the cleavage process, can then enter in central carbon catabolism (Todd et al., 2010, 2012b; Curson et al., 2011, 2014; Reisch et al., 2011b, 2013; Asao and Alber, 2013).

Within the Tara Oceans metatranscriptome data sets apportioned to marine bacteria, $d d d P, d d d K, d d d Q, d d d D$ and $d d d L$ transcripts were always detected, and were far more abundant than $d d d Y$ and $d d d W$, which was not detected (Curson et al., 2018). These results indicate that most of these bacterial DMSP cleavage genes are expressed in nature.

\section{Cleavage of DMSP by phytoplankton}

It has been known for many years that marine phytoplankton can cleave DMSP 
into DMS and acrylate (Table 3; Yoch, 2002), but a eukaryotic DMSP lyase gene, Alma1, was only identified recently by Alcolombri et al. (2015), in the haptophyte Emiliania huxleyi. Its product Alma1, which belongs to the aspartate racemase superfamily, generates DMS and acrylate from DMSP like the majority of the bacterial Ddd lyases (Table 3; Alcolombri et al., 2015). Based on protein sequence similarity, orthologues of Almal (and its paralogues) are present in a wide range of eukaryotes, including haptophytes, dinoflagellates and corals, highlighting a wide taxonomic distribution for this protein (Alcolombri et al., 2015). Alma1-like proteins of lesser sequence similarity are also present in some bacteria. Only Almal enzymes from $E$. huxleyi and Symbiodinium have been shown to have high DMSP lyase activity. Other homologues with lesser protein sequence similarity to the Alma1 from E. huxleyi, from the haptophyte Phaeocystis antarctica and the coral A. millepora, have extremely low DMSP lyase activities ( $<0.03 \%$ of the activity of the Symbiodinium Almal homologue and not much above the negative control) (Alcolombri et al., 2015). Thus, functional predictions based solely on sequence similarity are still very difficult and this makes predictions of their environmental importance very difficult without more functional ratification. Many other eukaryotes, like species in Chlorophyta, Rhodophyta and Alveolata, are also known to cleave DMSP into DMS and acrylate (Cantoni and Anderson, 1956; Stefels et al. 1993, 1995; Nishiguchi and Goff, 1995; Steinke et al., 2002; Yoch, 2002; Yost and Mitchelmore, 2009; Franklin et al., 2010; Niki et al., 2000), but the genes involved have not yet been identified, and further effort will be needed to uncover these.

\section{FUNCTIONS OF DMSP AND DMS}

\section{Ecological roles}

Marine microorganisms encounter and import DMSP in their natural habitat. They incorporate its sulfur into amino acids and utilise its three-carbon moiety for energy, which underlines the role of DMSP as one of the most important sulfur and carbon sources for many marine bacteria. Some bacteria, like SAR11, seem to be adapted to the use of reduced sulfur compounds such as DMSP, which represents the main ecologically relevant sulfur source that these bacteria are able to utilise, and genes for prominent alternative pathways for sulfur metabolism, such as sulfate reduction, have been lost (Tripp et al., 2008).

The process in which DMSP is degraded to DMS is also of great global significance as mentioned above. DMS is volatile and has low solubility, and is thus emitted in large amounts $\left(\sim 3 \times 10^{7}\right.$ tonnes per annum) from the oceans into the atmosphere. This represents the largest natural source of atmospheric sulfur and the major route for the transfer of sulfur from the oceans to the air, and contributes substantially to the global sulfur flux. DMS oxidation products, e.g., $\mathrm{SO}_{4}{ }^{2-}, \mathrm{S}_{2} \mathrm{O}_{3}{ }^{2-}$, 
$\mathrm{S}_{4} \mathrm{O}_{6}{ }^{2-}$ and DMSO, display longer residence time in the atmosphere than anthropogenically-derived $\mathrm{SO}_{2}$, and thus their contribution to the global sulfur burden is also greater (Lovelock et al., 1972; Chin and Jacob, 1996).

In the air, these DMS oxidation products act as condensation nuclei, causing water molecules to coalesce and form clouds. When returned to land via precipitation, this helps to bring marine sulfur to the continents, completing the global sulfur cycle since $\mathrm{SO}_{4}{ }^{2-}$ is transported from land via rivers to the oceans. The return of sulfur from the ocean to the land requires atmospheric sulfur volatiles, and DMS is the paramount compound among them. DMS-derived $\mathrm{SO}_{4}{ }^{2-}$ in the atmosphere acts in $\mathrm{CCN}$ formation, as described above, and the resulting increased cloud cover may influence local and possibly even global albedo, with a cooling effect on the climate (Figure 1 and Table 4; Kettle and Andreae, 2000; Simó, 2001). A negative feedback model has been suggested, in which the cooling effect due to increased DMS emission leads to a slower biomass production and thus a decreased production of DMSP and then its catabolite, DMS. This would then cause a consequent decrease in the cooling effect and increase in biomass production to complete the feedback loop (Charlson et al., 1987). However, this model has been challenged recently (Quinn and Bates, 2011).

\section{Physiological and biological functions}

Besides the great importance of DMSP and DMS in biogeochemical cycles and their potential effects on climate, these organosulfur molecules also have miscellaneous suggested physiological and biological functions in various marine species (Table 4). However there is little evidence at a molecular genetic level to verify these putative functions in any organism despite many of the proposed roles for these compounds being strongly suggested to be beneficial to phytoplankton and bacteria for survival in the marine environment.

\section{DMSP}

In phytoplankton and green algae, DMSP is proposed to have roles as an osmoprotectant, a cryoprotectant, a grazing deterrent, an antioxidant, a sink for excess sulfur, as well as other biological functions (Table 4).

For the organisms with high intracellular DMSP concentrations, this metabolite is present at physiologically relevant levels sufficient to be considered a major osmolyte, helping cells to overcome the adverse environment of hyperosmosis. For example, when exposed in high salt conditions, the intracellular DMSP concentration in Hymenomonas carterae cells can be as high as $300 \mathrm{mM}$ (Vairavamurthy et al., 1985; Kirst, 1990). In many DMSP-producers, DMSP is likely not the major osmolyte, with e.g. some nitrogen-containing osmolytes like glycine betaine, choline and carnitine adopting this function (Dickschat et al., 2015). DMSP was investigated for its 
cryoprotective activity on the model enzymes lactate dehydrogenase (LDH) and malate dehydrogenase (MDH), which were extracted from the polar alga Aerosiphonia arela (Chlorophyta; Karsten et al., 1996). Both of the activities and stabilities of LDH and MDH under freezing conditions were risen with the addition of DMSP. DMSP produced by E. huxleyi, and its degradation products acrylate and acryloyl-CoA, have certain toxic effects on many organisms, and are thought to act as predator deterrents, thus increasing the chance of E. huxleyi survival (Wolfe and Steinke, 1996; Wolfe et al., 1997). DMSP and its breakdown products, e.g., DMS, acrylate, DMSO and acrylate can scavenge hydroxyl radicals and other reactive oxygen species, and thus they may serve as highly effective antioxidants (Sunda et al., 2002; Lesser 2006; Husband et al., 2012; Curson et al., 2018). DMSP biosynthesis is suggested to provide sinks for the excess energy, carbon and reducing equivalents derived from active photosynthesis, saving nitrogen for cell growth and accelerating sulfate uptake from the environment (Gage et al., 1997; Stefels, 2000; Bullock et al., 2017).

DMSP can also be a signal molecule, attracting specific groups of bacteria and structuring the microbial communities that are integrally associated with corals and other organisms, underpinning their health (Raina et al., 2013). Similarly, it can attract several phytoplankton and bacterivore and herbivore microzooplankton (Seymour et al., 2010). Apart from these microorganisms, DMSP can provide underwater foraging cues for some reef fish (DeBose et al., 2008). As a chemical signaling molecule, DMSP may induce bacterial quorum sensing, e.g., participating in the degradation of particulate organic matter (POC) (Seyedsayamdost et al., 2011; Johnson et al., 2016). As a mediator of bacterial virulence, DMSP may regulate the demise of E. huxleyi blooms (Barak-Gavish et al., 2018).

\section{DMS}

DMS is the cue for chemosensory attraction for marine invertebrates and bacteria that feed on DMSP-producing phytoplankton (Table 4; Zimmer-Faust et al., 1996; Steinke et al., 2006). In addition, as mentioned above, the grazing zooplankton cause the degradation of algal DMSP to DMS and acrylate, which act as feeding deterrents towards the protozoan herbivores, thus representing a chemical defense mechanism of the phytoplankton (Wolfe and Steinke, 1996; Wolfe et al., 1997). The resulting increased emission of DMS into the atmosphere upon grazing is in turn also recognised by seabirds that feed on the grazing zooplankton (Nevitt and Bonadonna, 2005).

\section{CONCLUSION AND PROSPECT}

In summary, DMS and DMSP play important roles in driving global sulfur cycling and may affect climate. It is now clear that both prokaryotes (e.g., bacteria) and eukaryotes (e.g., algae) can synthesise and degrade DMSP. However, their relative contributions to environmental DMSP production and cleavage have not been clearly 
quantified, and the ways in which they are affected by and impinge on environmental parameters has not been elucidated either. Since it has long been thought that DMSP can only be produced by marine photosynthetic organisms, studies on the distribution and concentration of DMSP and DMS were mainly limited to the marine euphotic layers, while in the deeper ocean and sediments, they have been largely ignored. According to the limited data available (Curran et al., 1998; Li et al., 2015; Zhai et al., 2018), absolute concentrations of DMSP and DMS in the deeper ocean are relatively low, but on a global scale, DMSP and DMS in deep oceans should be investigated further due to the immense water volume and bacterial biomass in this biosphere.

Considering heterotrophic bacteria are chemoheterotrophic and that phytoplankton are photoautotrophic, we propose the hypothesis that phytoplankton are only the major contributor to DMSP production at euphotic depths, while in deeper oceans where limited or even no sunlight penetrate, the relative contribution of heterotrophic bacteria to DMSP production may become dominant.

Since the discovery of DMSP biosynthesis in marine heterotrophic bacteria and the identification of the key gene $d s y B$ in this process, many other heterotrophic bacteria have also been found to produce DMSP. However, among some of the genomes of these newly discovered DMSP-producing bacteria and the transcriptomes of many eukaryotes, no homologue of $D s y B / D S Y B / T p M M T$ was detected. This indicates that different isozymes or even DMSP biosynthesis pathways exist in these strains to be further explored. As for DMSP degradation, no homologues of the known Almal and $d d d$ DMSP lyase genes were detected in the transcriptomes of the DMSP-cleaving eukaryote Ulva and the genomes of $\mathrm{Ddd}^{+}$prokaryotic Actinobacteria, so novel DMSP cleavage gene(s) still exist to be discovered.

Many marine bacteria (e.g., L. aggregata and Pseudooceanicola batsensis) and algae (e.g., E. huxleyi and Phaeocystis sp.) not only make DMSP but also cleave this compound (Stefels and Dijkhuizen, 1996; Alcolombri et al., 2015; Curson et al., 2017). What are the endogenous and/or external incentives for this ability? What is its physiological relevance? How are these contradictory processes being precisely regulated in one organism? The functions of DMSP and DMS in marine organisms still need to be verified at a molecular genetic level. These unanswered questions could be the focus for our future in-depth studies on the molecular mechanisms of DMSP biosynthesis and degradation, and their relevant functions in driving the global sulfur cycle.

\section{Acknowledgements}

This work was financially supported by the National Natural Science Foundation of China (91751202 and 41730530), the National Key Research and Development Program of China (2016YFA0601303 and 2018YFC0310701), and the Marine S\&T 

grants (NE/N002385, NE/P012671 and NE/S001352) fund ARJC and JDT.

\section{References}

Alcolombri, U., Laurino, P., Lara-astiaso, P., and Vardi, A. (2014). DddD is a CoA-transferase/lyase producing dimethyl sulfide in the marine environment. Biochemistry 53, 5473-5475.

Alcolombri, U., Ben-Dor, S., Feldmesser, E., Levin, Y., Tawfik, D.S., and Vardi, A. (2015). Identification of the algal dimethyl sulfide-releasing enzyme: A missing link in the marine sulfur cycle. Science 348, 1466-1469.

Anderson, D.G., and Cantoni, G.L. (1956). Enzymatic cleavage of dimethylpropiothetin by Polysiphonia Lanosa. J Biol Chem 222, 171-177.

Andreae, M.O., Ferek, R.J., Bermond, F., Byrd, K.P., Engstrom, R.T., Hardin, S., Houmere, P.D., LeMarrec, F., Raemdonck, H., and Chatfield, R.B. (1985). Dimethyl sulfide in the marine atmosphere. J Geophys Res 90, 12891-12900.

Andreae, M.O. (1990). Ocean-atmosphere interactions in the global biogeochemical sulfur cycle. Mar Chem 30, 1-29.

Andreae, M.O., and Crutzen, P. (1997). Atmospheric aerosol: Biogeochemical sources and role in atmospheric chemistry. Science 276, 1052-11058.

Andreae, M.O., Berresheim, H., Andreae, T.W., Kritz, M.A., Bates, T.S., and Merrill, J.T. (1988). Vertical distribution of dimethylsulfide, sulfur dioxide, aerosol ions, and radon over the northeast Pacific Ocean. J Atmos Chem 6,149-173.

Aranami, K., and Tsunogai, S. (2004). Seasonal and regional comparison of oceanic and atmospheric dimethylsulfide in the northern North Pacific: Dilution effects on its concentration during winter. J Geophys Res-Atmos 109, D12303.

Aranami, K., Watanabe, S., Tsunogai, S., Hayashi, M., Furuya, K., and Nagata, T. (2001), Biogeochemical variation in dimethylsulfide, phytoplankton pigments and heterotrophic bacterial production in the subarctic North Pacific during summer. J Oceanogr 57, 315-322.

Archer, S.D., Widdicombe, C.E., Tarran, G.A., Rees, A.P., and Burkill, P.H. (2001). Production and turnover of particulate dimethylsulphoniopropionate during a coccolithophore bloom in the northern North Sea. Aquat Microb Ecol 24, 225-241.

Archer, S.D., Cummings, D.G., Llewellyn, C.A., and Fishwick, J. R. (2009). Phytoplankton taxa, irradiance and nutrient availability determine the seasonal cycle of DMSP in temperate shelf seas. Mar Ecol Prog Ser 394, 111-124.

Asao, M., and Alber, B.E. (2013). Acrylyl-CoA reductase, an enzyme involved in the assimilation of 3-hydroxypropionate by Rhodobacter sphaeroides. J Bacteriol 195, 4716-4725 .

Ausma, T., Kebert, M., Stefels, J., and De Kok, L.J. (2017). DMSP: Occurrence in plants and response to salinity in Zea mays. In: Sulfur Metabolism in Higher Plants-Fundamental, Environmental and Agricultural Aspects (Cham: Springer), pp. 87-91.

Ayers, G.P., and Gras, J.L. (1991). Seasonal relationship between cloud condensation nuclei and aerosol methanesulphonate in marine air. Nature 353, 834-835.

Barak-Gavish, N., Frada, M.J., Lee, P.A, DiTullio, G.R., Ku, C., Malitsky, S., Aharoni, A., Green, S.J., Rotkopf, R., Kartvelishvily, E., et al. (2018). Bacterial virulence against an oceanic bloomforming phytoplankter is mediated by algal DMSP. Sci Adv 4, 1-38.

Bates, T.S., and Quinn, P.K. (1997). Dimethylsulfide (DMS) in the equatorial Pacific Ocean (1982 to 1996): Evidence of a climate feedback. Geophys Res Lett 24, 861-864.

Belviso, S., Bopp, L., Mosseri, J., Tedetti, M., Garcia, N., Griffiths, B. Joux, F., Obernosterer, I., Uitz, J., and Veldhuis, M.J.W. (2008). Effect of natural iron fertilisation on the distribution of DMS and DMSP in the Indian sector of the Southern Ocean. Deep Sea Res Part 2 Top Stud Oceanogr 55, 893-900.

Belviso, S., Sciandra, A., and Copin-Montégut, C. (2003) Mesoscale features of surface water DMSP and DMS concentrations in the Atlantic Ocean off Morocco and in the Mediterranean 
Sea. Deep Sea Res Part 1 Oceanogr Res Pap 50, 543-555.

Belviso, S., Buat-Ménard, P., Putaud, J.P., Nguyen, B.C., Claustre, H., and Neveux, J. (1993). Size distribution of dimethylsulfoniopropionate (DMSP) in areas of the tropical northeastern Atlantic Ocean and the Mediterranean Sea. Mar Chem 44, 55-71.

Bischoff, B., Karsten, U., Daniel, C., Kuck, K., Xia, B., and Wiencke, C. (1994). Preliminary assessment of the $\beta$-dimethylsulfoniopropionate (DMSP) content of macroalgae from the tropical island of hainan (People's Republic of China). Mar Freshw Res, 45, 1329--1336.

Boucher, O., and Pham, M. (2002). History of sulfate aerosol radiative forcings. Geophys Res Lett, 29, 22-1-22-4.

Brummett, A.E., Schnicker, N.J., Crider, A., Todd, J.D., and Dey, M. (2015). Biochemical, kinetic, and spectroscopic characterization of Ruegeria pomeroyi DddW-A mononuclear irondependent DMSP lyase. PLoS One 10, e0127288.

Brummett, A.E., and Dey, M. (2016). New Mechanistic insight from substrate-and product-bound structures of the metal-dependent dimethylsulfoniopropionate lyase DddQ. Biochemistry 55, 6162-6174.

Bullock, H.A., Luo, H., and Whitman, W.B. (2017), Evolution of Dimethylsulfoniopropionate Metabolism in Marine Phytoplankton and Bacteria. Front Microbiol 8, e0127288.

Bürgermeister, S., Zimmermann, R.L., Georgii, H.W., Bingemer, H.G., Kirst, G.O., Janssen, M., and Ernst, W. (1990), On the biogenic origin of dimethylsulfide: relation between chlorophyll, ATP, organismic DMSP, phytoplankton species, and DMS distribution in Atlantic surface water and atmosphere. J Geophys Res Atmos 95, 20607-20615.

Cantin, G., Levasseur, M., Gosselin, M., and Michaud, S. (1996). Role of zooplankton in the mesoscale distribution of surface dimethylsulfide concentrations in the Gulf of St. Lawrence. Canada. Mar Ecol-Prog Ser 141, 103-117.

Cantoni, G.L., and Anderson, D.G. (1956). Enzymatic cleavage of dimethylpropiothetin by Polysiphonia lanosa. J Biol Chem 222, 171-177.

Carrión, O., Curson, A.R.J., Kumaresan, D., Fu, Y., Lang, A.S., Mercadé, E., and Todd, J. D. (2015). A novel pathway producing dimethylsulphide in bacteria is widespread in soil environments. Nat Commun, 6, e7579.

Carrión, O., Pratscher, J., Curson, A.R., Williams, B.T., Rostant, W.G., Murrell, J.C., and Todd, J.D. (2017). Methanethiol-dependent dimethylsulfide production in soil environments. ISME J 11, 2379-2390.

Caruana, A. (2010). DMS and DMSP production by marine dinoflagellates. Doctoral Dissertation. Norwich: University of East Anglia.

Challenger, F., and Simpson, M.I. (1948). Studies on biological methylation; a precursor of the dimethyl sulphide evolved by Polysiphonia fastigiata; dimethyl-2-carboxyethylsulphonium hydroxide and its salts. J Chem Soc 3, 1591-1597.

Charlson. R.J., Lovelock, J.E., Andreae, M.O., and Warren, S.G. (1987). Oceanic phytoplankton, atmospheric sulphur, cloud albedo and climate. Nature 326, 655-661.

Chillemi, R., Patti, A., Morrone, R., Piattelli, M., and Sciuto, S. (1990). The role of methylsulfonium compounds in the biosynthesis of N-methylated metabolites in Chondria coerulescens. J Nat Prod 53, 87-93.

Chin, M., and Jacob, D.J. (1996). Anthropogenic and natural contributions to tropospheric sulfate: A global model analysis. J Geophys Res Atmos 101, 18691-18699.

Cui, Y., Suzuki, S., Omori, Y., Wong, S.K., Ijichi, M., Kaneko, R., Kameyama, S., Tanimoto. H., and Hamasaki, K. (2015). Abundance and distribution of dimethylsulfoniopropionatedegrading genes and the corresponding bacterial community structure at dimethyl sulfide hotspots in the tropical and subtropical Pacific Ocean. Appl Environ Microbiol 81, 4184-4194.

Curran, M.A., Jones, G.B., and Burton, H. (1998). Spatial distribution of dimethylsulfide and dimethylsulfoniopropionate in the Australasian sector of the Southern Ocean. J Geophys Res Atmos 103, 16677-16689.

Curson, A.R., Burns, O.J., Voget, S., Daniel, R., Todd, J.D., McInnis, K., Wexler, M., and Johnston, A.W.B. (2014). Screening of metagenomic and genomic libraries reveals three classes of bacterial enzymes that overcome the toxicity of acrylate. PLoS One 9, e97660. 
Curson, A.R.J., Liu, J., Martínez, A.B., Green, R.T., Chan, Y., Carrión, O., Williams, B.T., Zhang, S.-H., Yang, G.-P., Page, P.C.B., et al. (2017). Dimethylsulfoniopropionate biosynthesis in marine bacteria and identification of the key gene in this process. Nat Microbiol 2, e17009.

Curson, A.R.J., Todd, J.D., Sullivan, M.J., and Johnston, A.W.B. (2011a). Catabolism of dimethylsulphoniopropionate: Microorganisms, enzymes and genes. Nat Rev Microbiol 9, 849-859.

Curson, A.R.J., Sullivan, M.J., Todd, J.D., and Johnston, A.W.B. (2011b). DddY, a periplasmic dimethylsulfoniopropionate lyase found in taxonomically diverse species of Proteobacteria. ISME J 5, 1191-1200.

Curson, A.R.J, Williams, B.T., Pinchbeck, B.J., Sims, L.P., Martínez, A.B., Rivera, P.P.L, Kumaresan, D., Mercadé, E., Spurgin, L.G., Carrión, O., et al. (2018). DSYB catalyses the key step of dimethylsulfoniopropionate biosynthesis in many phytoplankton. Nat Microbiol 3, $430-439$.

Dacey, J.W., Howse, F.A., Michaels, A.F., and Wakeham, S.G. (1998). Temporal variability of dimethylsulfide and dimethylsulfoniopropionate in the Sargasso Sea. Deep Sea Res Part 1 Oceanogr Res Pap 45, 2085-2104.

Dacey, J.W.H., and Wakeham, S.G. (1986) Oceanic dimethyl sulfide: production during zooplankton grazing on phytoplankton. Science 233, 1314-1316.

Damm, E., Nomura, D., Martin, A., Dieckmann, G.S., and Meiners, K.M. (2016). DMSP and DMS cycling within Antarctic sea ice during the winter-spring transition. Deep Sea Res Part 2 Top Stud Oceanogr 131, 150-159.

DeBose, J.L., and Nevitt, G.A. (2008). The use of odors at different spatial scales: comparing birds with fish. J Chem Ecol 34, 867-881.

DeBose, J.L., Lema, S.C., and Nevitt, G. A. (2008). Dimethylsulfoniopropionate as a foraging cue for reef fishes. Science 319, 1356-1356.

Diaz, M.R., and Taylor, B.F. (1994). Comparison of dimethylsulfoniopropionate (DMSP) lyase activity in a procaryote and a eukaryote. Abstr 94th Gen Meet Am Soc Microbiol (Washington DC: Am Soc Microbiol), pp.319.

Dickson, D.M.J., and Kirst., G.O. (1986) The role of dimethylsulfoniopro-pionate, glycine betaine and homarine in the osmoacclimation of Platymonas subcordiformis. Planta 167, 536-543.

Dickschat, J.S., Rabe, P., and Citron, C.A. (2015). The chemical biology of dimethylsulfoniopropionate. Org Biomol Chem 13, 1954-1968.

Franklin, D.J., Steinke, M., Young. J., Probert, I., and Malin, G. (2010). Dimethylsulphoniopropionate (DMSP), DMSP lyase activity (DLA) and dimethylsulphide (DMS) in 10 species of coccolithophore. Mar Ecol Prog Ser 410, 13-23.

Gage, D.A., Rhodes, D., Nolte, K.D., Hicks, W.A., Leustek, T., Cooper, A.J.L., and Hanson, A.D. (1997). A new route for synthesis of dimethylsulphoniopropionate in marine algae. Nature 387 , 891-894.

González, J.M., Kiene, R.P., and Moran, M.A. (1999). Transformation of sulfur compounds by an abundant lineage of marine bacteria in the $\alpha$-subclass of the class Proteobacteria. Appl Environ Microbiol 65, 3810-3819.

Greene, R.C. (1962). Biosynthesis of dimethyl- $\beta$-propiothetin. J Biol Chem 237, 2251-2254.

Hanson, A.D., Rivoal, J., and Gage, D.A. (1994). Biosynthesis of 3-dimethylsulfoniopropionate in Wollastonia biflora (L.) DC.: Evidence that $S$-methylmethionine is an intermediate. Plant Physiol 105, 103-110.

Hanson, A.D., and Gage, D.A. (1996). 3-Dimethylsulfoniopionate biosynthesis and use by flowering plants. In: Biological and Environmental Chemistry of DMSP and Related Sulfonium Compounds (Boston, MA: Springer), pp. 75-86.

Hehemann, J.H., Law, A., Redecke, L., and Boraston, A.B. (2014). The structure of RdDddP from Roseobacter denitrificans reveals that DMSP lyases in the DddP-family are metalloenzymes. PLoS One 9, e103128.

Hill, R.W., White, B.A., Cottrell, M.T., and Dacey, J.W.H. (1998). Virus-mediated total release of dimethylsulfoniopropionate from marine phytoplankton: A potential climate process. Aquat Microb Ecol 14, 1-6.

Howard, E.C., Henriksen, J.R., Buchan, A., Reisch, C.R., Bürgmann, H., Welsh, R., Ye, W., 
González, J.M., Mace, K., Joye S.B., et al. (2006). Bacterial taxa that limit sulfur flux from the ocean. Science 314, 649-652.

Husband, J.D., Kiene, R.P., and Sherman, T.D. (2012). Oxidation of dimethylsulfoniopropionate (DMSP) in response to oxidative stress in Spartina alterniflora, and protection of a non-DMSP producing grass by exogenous DMSP + acrylate. Environ Exp Bot 79, 44-48.

Iverson, R.L., Nearhoof, F.L., and Andreae, M.O. (1989). Production of dimethylsulfonium propionate and dimethylsulfide by phytoplankton in estuarine and coastal waters. Limnol Oceanogr 34, 53-67.

Ito, T., Asano, Y., Tanaka, Y., and Takabe, T. (2011) Regulation of biosynthesis of dimethylsulfoniopropionate and its uptake in sterile mutant of Ulva pertusa (Chlorophyta). J Phycol 47, 517-523.

James, F., Paquet, L., Sparace, S.A., Gage, D.A., and Hanson, A.D. (1995). Evidence implicating dimethylsulfoniopropionaldehyde as an intermediate in dimethylsulfoniopropionate biosynthesis. Plant Physiol 108, 1439-1448.

Jarníková, T., Dacey, J., Lizotte, M., Levasseur, M., and Tortell, P. (2018). The distribution of methylated sulfur compounds, DMS and DMSP, in Canadian subarctic and Arctic marine waters during summer 2015. Biogeosciences 15, 2449-2465.

Johnson, W.M., Soule, M.C.K., and Kujawinski, E.B. (2016). Evidence for quorum sensing and differential metabolite production by a marine bacterium in response to DMSP. ISME J 10, 2304-2316.

Johnston, A.W., Green, R.T., and Todd, J.D. (2016). Enzymatic breakage of dimethylsulfoniopropionate - a signature molecule for life at sea. Curr Opin Chem Biol 31, 58-65.

Kageyama, H., Tanaka, Y., Shibata, A., Waditee-Sirisattha, R., and Takabe, T. (2018). Dimethylsulfoniopropionate biosynthesis in a diatom Thalassiosira pseudonana: Identification of a gene encoding MTHB-methyltransferase. Arch Biochem Biophys 645, 100-106.

Karsten, U., Kück, K., Vogt, C., and Kirst, G.O. (1996). Dimethylsulfoniopropionate production in phototrophic organisms and its physiological functions as a cryoprotectant. In: Biological and Environmental Chemistry of DMSP and Related Sulfonium Compounds (Boston MA: Springer), pp. 143-153.

Keller, M.D., Bellows, W.K., and Guillard, R.R.L. (1989). Dimethyl sulfide production in marine phytoplankton. In: Biogenic Sulfur in the Environment, E. Saltzman, and W. Cooper, eds. (Washington, DC: American Chemical Society), pp. 167-182.

Keller, M.D., and Korjeff-Bellows, W. (1996). Physiological aspects of the production of dimeyhtlsulfoniopropionate (DMSP) by marine phytoplankton. In Biological and environmental chemistry of DMSP and related sulfonium compounds (Boston, MA: Springer), pp.131-142.

Kettle, A.J., and Andreae, M.O. (2000). Flux of dimethylsulfide from the oceans: A comparison of updated data sets and flux models. J Geophys Res Atmos 105, 26793-26808.

Kettles, N.L., Kopriva, S., and Malin, G. (2014). Insights into the regulation of DMSP synthesis in the diatom Thalassiosira pseudonana through APR activity, proteomics and gene expression analyses on cells acclimating to changes in salinity, light and nitrogen. PLoS One 9, e94795.

Kiene, R.P., Kieber, D.J., Slezak, D., Toole, D.A., del Valle, D.A., Bisgrove, J., Brinkley, J., and Rellinger, A. (2007). Distribution and cycling of dimethylsulfide, dimethylsulfoniopropionate, and dimethylsulfoxide during spring and early summer in the Southern Ocean south of New Zealand. Aquat Sci 69, 305-319.

Kiene, R.P., Linn, L.J., and Bruton, J.A. (2000). New and important roles for DMSP in marine microbial communities. J Sea Res 43, 209-224.

Kiene, R.P., and Linn, L.J. (2000). The fate of dissolved dimethylsulfoniopropionate (DMSP) in seawater: tracer studies using ${ }^{35}$ S-DMSP. Geochim Cosmochim Acta 64, 2797-2810.

Kirkwood, M., Le Brun, N.E., Todd, J.D., and Johnston, A.W.B. (2010). The $d d d P$ gene of Roseovarius nubinhibens encodes a novel lyase that cleaves dimethylsulfoniopropionate into acrylate plus dimethyl sulfide. Microbiology 156, 1900-1906.

Kirst, G.O. (1990). Salinity tolerance of eukaryotic marine algae. Annu Rev Plant Physiol Plant Mol Biol 41, 21-53. 
Kitaguchi, H., Uchida, A., and Ishida, Y. (2008). Purification and characterization of L-methionine decarboxylase from. Fisheries Sci 65, 613-617.

Kocsis, M.G., Nolte, K.D., Rhodes, D., Shen, T.L., Gage, D.A., and Hanson, A.D. (1998). Dimethylsulfoniopropionate biosynthesis in Spartina alterniflora: Evidence that $S$ methylmethionine and dimethylsulfoniopropylamine are intermediates. Plant Physiol 117, 273-281.

Ksionzek, K.B., Lechtenfeld, O.J., McCallister, S.L., Schmitt-Kopplin, P., Geuer, J.K., Geibert, W., and Koch, B.P. (2016). Dissolved organic sulfur in the ocean: Biogeochemistry of a petagram inventory. Science 354, 456-459.

Ku, C., Nelson-Sathi, S., Roettger, M., Sousa, F.L., Lockhart, P.J., Bryant, D., Hazkani-Covo, E., McInerney, J.O., Landan, G., and Martin, W.F. (2015). Endosymbiotic origin and differential loss of eukaryotic genes. Nature 524, 427-432.

Lei, L., Cherukuri, K.P., Alcolombri, U., Meltzer, D., and Tawfik, D.S. (2018). The Dimethylsulfoniopropionate (DMSP) lyase and lyase-like cupin family consists of bona fide DMSP lyases as well as other enzymes with unknown function. Biochemistry 57, 3364-3377.

Lesser, M.P. (2006). Oxidative stress in marine environments: biochemistry and physiological ecology. Annu Rev Physiol 68, 253-278.

Li, C.X., Wang, B.D., and Yang, G.P. (2015). Spatial distributions of Dimethylsulfide (DMS) and influencing factors in the Norwegian and Greenland seas during summer. Haiyang Xuebao 37 , 9-25. (in Chinese, abstract in English)

Li, C.-Y., Wei, T.-D., Zhang, S.-H., Chen, X.-L., Gao, X., Wang, P., Xie B.-B., Su, H.-N., Qin, Q.L., Zhang, X.-Y., et al. (2014). Molecular insight into bacterial cleavage of oceanic dimethylsulfoniopropionate into dimethyl sulfide. Proc Natl Acad Sci U S A 111, 1026-1031.

Li, C.Y., Zhang, D., Chen, X.L., Wang, P., Shi, W.L., Li, P.Y., Zhang X.Y., Qin Q.L., Todd J.D., and Zhang, Y.Z. (2017). Mechanistic insights into dimethylsulfoniopropionate lyase DddY, a new member of the cupin superfamily. J Mol Biol 429, 3850-3862.

Locarnini, S.J.P., Turner, S.M., and Liss, P.S. (1998). The distribution of dimethylsulfide, DMS, and dimethylsulfoniopropionate, DMSP, in waters off the Western Coast of Ireland. Cont Shelf Res $18,1455-1473$.

Lovelock, J. (2006). The Revenge of Gaia: Earth's Climate in Crisis and the Fate of Humanity. New York: Basic Books.

Lovelock, J.E., Maggs, R.J., and Rasmussen, R.A. (1972). Atmospheric dimethyl sulfide and the natural sulfur cycle. Nature 237, 452-453.

Lyon, B.R., Lee, P.A., Bennett, J.M., DiTullio, G.R., and Janech, M.G. (2011). Proteomic analysis of a sea-ice diatom: salinity acclimation provides new insight into the dimethylsulfoniopropionate production pathway. Plant Physiol 157, 1926-1941.

Malin, G., Turner, S., Liss, P., Holligan, P., and Harbour, D. (1993). Dimethylsulphide and dimethylsulphoniopropionate in the Northeast Atlantic during the summer coccolithophore bloom. Deep Sea Res Part 1 Oceanogr Res Pap 40, 1487-1508.

Malmstrom, R.R., Kiene, R.P., Cottrell, M.T., and Kirchman, D.L. (2004). Contribution of SAR11 bacteria to dissolved dimethylsulfoniopropionate and amino acid uptake in the North Atlantic Ocean. Appl Environ Microbiol 70, 4129-4135.

Mara, P., Psarra, S., Tselepides, A., Eleftheriou, A., and Mihalopoulos, N. (2015). Influence of phytoplankton taxonomic profile on the distribution of total and dissolved dimethylated sulphur (DMSx) species in the North Aegean Sea (Eastern Mediterranean). Mediterr Mar Sci 17, 65-79.

Matrai, P.A., and Keller, M.D. (1993). Dimethylsulfide in a large-scale coccolithophore bloom in the Gulf of Maine. Cont Shelf Res 13, 831-843.

Matrai, P.A., and Vernet, M. (1997). Dynamics of the vernal bloom in the marginal ice zone of the Barents Sea: Dimethyl sulfide and dimethylsulfoniopropionate budgets. J Geophys Res Oceans 102, 22965-22979.

Meyerdierks, D., Bolt, B., and Kirst, G.O. (1997). Spatial and vertical distribution of particulate dimethylsulphoniopropionate (DMSP) during spring in the Atlantic sector of the Southern Ocean. Deep Sea Res Part 2 Top Stud Oceanogr 44, 283-297.

Miller, T.R., Hnilicka, K., Dziedzic, A., Desplats, P., and Belas, R. (2004). Chemotaxis of 
Silicibacter sp. strain TM1040 toward dinoflagellate products. Appl Environ Microbiol 70, 4692-4701.

Motard-Côté, J., Kieber, D.J., Rellinger, A., and Kiene, R.P. (2016). Influence of the Mississippi River plume and non-bioavailable DMSP on dissolved DMSP turnover in the northern Gulf of Mexico. Environ Chem 13, 280-292.

Motard-Côté, J., Levasseur, M., Scarratt, M.G., Michaud, S., Gratton, Y., Rivkin, R.B., Keats, K., Gosselin, M., Tremblay, J.-É., Kiene, R.P., et al. (2012). Distribution and metabolism of dimethylsulfoniopropionate (DMSP) and phylogenetic affiliation of DMSP-assimilating bacteria in northern Baffin Bay/Lancaster Sound. J Geophys Res Oceans 117, C00G11.

Nevitt, G.A. (2008). Sensory ecology on the high seas: the odor world of the procellariiform seabirds. J Exp Biol 211, 1706-1713.

Nevitt, G.A., and Bonadonna, F. (2005). Sensitivity to dimethyl sulphide suggests a mechanism for olfactory navigation by seabirds. Biol Lett 1, 303-305.

Niki, T., Kumugi, M., Kohata, K., and Otsuki, A. (1997). Annual monitoring of DMS-producing bacteria in Tokyo Bay, Japan, in relation to DMSP. Mar Ecol Prog 156, 17-24.

Niki, T., Kunugi, M., and Otsuki, A. (2000). DMSP-lyase activity in five marine phytoplankton species: Its potential importance in DMS production. Mar Biol 136, 759-764.

Nishiguchi, M.K., and Goff, L.J. (1995). Isolation, purification, and characterization of DMSP lyase (dimethylpropiothetin dethiomethylase [4.4.1.3]) from the red alga Polysiphonia paniculata. J Phycol 31, 567-574.

Otte, M.L., Wilson, G., Morris, J.T., and Moran, B.M. (2004). Dimethylsulphoniopropionate (DMSP) and related compounds in higher plants. J Exp Bot 55, 1919-1925.

Paquet, L., Rathinasabapathi, B., Saini, H., Zamir, L., Gage, D.A., Huang, Z.H., and Hanson, A.D. (1994). Accumulation of the compatible solute 3-dimethylsulfoniopropionate in sugarcane and its relatives, but not other gramineous crops. Aust J Plant Physiol 21, 37-48.

Quinn, P.K., and Bates, T.S. (2011). The case against climate regulation via oceanic phytoplankton sulphur emissions. Nature 480, 51-56.

Raina, J.B., Tapiolas, D., Willis, B.L., and Bourne, D. G. (2009). Coral-associated bacteria and their role in the biogeochemical cycling of sulfur. Appl Environ Microbiol 75, 3492-3501.

Raina, J.B., Tapiolas, D.M., Forêt, S., Lutz, A., Abrego, D., Ceh, J., Seneca, F.O., Clode, P.L., Bourne, D.G., Willis, B.L., et al. (2013). DMSP biosynthesis by an animal and its role in coral thermal stress response. Nature 502, 677-680.

Raina, J.B., Clode, P.L., Cheong, S., Bougoure, J., Kilburn, M.R., Reeder, A., Foret, S.; Stat, M.; Beltran, V., Thomas-Hall, P. et al. (2017). Subcellular tracking reveals the location of dimethylsulfoniopropionate in microalgae and visualises its uptake by marine bacteria. eLife, 6, e23008.

Rao, V.D., Viswanadham, R., Bharathi, M.D., Sarma, V.V.S.S., and Kumar, M.D. (2015). Impact of river discharge on distribution of dimethyl sulfide (DMS) and its fluxes in the coastal Bay of Bengal. J Sea Res 103, 32-41.

Reed, R.M. (1983). Measurement and osmotic significance of $\beta$-dimethylsulfonio-propionate in marine macroalgae. Marine Biol Lett, 4, 173-181.

Reisch, C.R., Moran, M.A., and Whitman, W.B. (2008). Dimethylsulfoniopropionate-dependent demethylase (DmdA) from Pelagibacter ubique and Silicibacter pomeroyi. J Bacteriol 190, 8018-8024.

Reisch, C.R., Stoudemayer, M.J., Varaljay, V.A., Amster, I.J., Moran, M.A., and Whitman, W. B. (2011a). Novel pathway for assimilation of dimethylsulphoniopropionate widespread in marine bacteria. Nature 473, 208-213.

Reisch, C.R., Moran, M.A., and Whitman, W.B. (2011b). Bacterial catabolism of dimethylsulfoniopropionate (DMSP). Front Microbiol 2, 172.

Reisch, C.R., Crabb, W.M., Gifford, S.M., Teng, Q., Stoudemayer, M.J., Moran, M.A., and Whitman, W.B. (2013). Metabolism of dimethylsulphoniopropionate by Ruegeria pomeroyi DSS-3. Mol Microbiol 89, 774-791.

Rellinger, A.N., Kiene, R.P., del Valle, D.A., Kieber, D.J., Slezak, D., Harada, H., Bisgrove, J., and Brinkley, J. (2009). Occurrence and turnover of DMSP and DMS in deep waters of the Ross Sea, Antarctica. Deep Sea Res Part 1 Oceanogr Res Pap 56, 686-702. 
Scarratt, M.G., Levasseur, M., Michaud, S., Cantin, G., Gosselin, M., and De Mora, S.J. (2002). Influence of phytoplankton taxonomic profile on the distribution of dimethylsulfide and dimethylsulfoniopropionate in the northwest Atlantic. Mar Ecol Prog Ser 244, 49-61.

Scarratt, M.G., Levasseur, M., Michaud, S., and Roy, S. (2007). DMSP and DMS in the Northwest Atlantic: Late-summer distributions, production rates and sea-air fluxes. Aquat Sci 69, 292304.

Schnicker, N.J., De Silva, S.M., Todd, J.D., and Dey, M. (2017). Structural and biochemical insights into dimethylsulfoniopropionate cleavage by cofactor-bound DddK from the prolific marine bacterium Pelagibacter. Biochemistry 56, 2873-2885.

Sciare, J., Mihalopoulos, N., and Nguyen, B.C. (1999). Summertime seawater concentrations of dimethylsulfide in the western Indian Ocean: Reconciliation of fluxes and spatial variability with long-term atmospheric observations. J Atmos Chem 32, 357-373.

Seyedsayamdost, M.R., Case, R.J., Kolter, R., and Clardy, J. (2011). The Jekyll-and-Hyde chemistry of Phaeobacter gallaeciensis. Nat Chem 3, 331-335.

Seymour, J.R., Simó, R., Ahmed, T., and Stocker, R. (2010). Chemoattraction to dimethylsulfoniopropionate throughout the marine microbial food web. Science 329, 342-345.

Simó, R. (2001). Production of atmospheric sulfur by oceanic plankton: biogeochemical, ecological and evolutionary links. Trends Ecol Evol 16, 287-294.

Simo, R., Grimalt, J.O., and Albaigés, J. (1997). Dissolved dimethylsulphide, dimethylsulphoniopropionate and dimethylsulphoxide in western Mediterranean waters. Deep Sea Res Part 2 Top Stud Oceanogr 44, 929-950.

Simó, R., and Pedrós-Alió, C. (1999). Role of vertical mixing in controlling the oceanic production of dimethyl sulphide. Nature 402, 396-399.

Song, Y.Z., Zhang H.H., and Yang, G.P. (2014). Distributions of dimethylsulfide and dimethylsulfoniopropionate and influencing factors in the East China Sea and the Southern Yellow Sea during the winter. Huan Jing Ke Xue 6, 2067-2074. (in Chinese, abstract in English)

Speeckaert, G., Borges, A.V., Champenois, W., Royer, C., and Gypens, N. (2018). Annual cycle of dimethylsulfoniopropionate (DMSP) and dimethylsulfoxide (DMSO) related to phytoplankton succession in the Southern North Sea. Sci Total Environ 622, 362-372.

Spielmeyer, A., and Pohnert, G. (2012). Influence of temperature and elevated carbon dioxide on the production of dimethylsulfoniopropionate and glycine betaine by marine phytoplankton. Mar Environ Res 73, 62-69.

Stefels, J., and Boekel, W.V. (1993). Production of DMS from dissolved DMSP in axenic cultures of the marine phytoplankton species Phaeocystis sp. Mar Ecol Prog Ser 97, 11-18.

Stefels, J., and Dijkhuizen, L. (1996). Characteristics of DMSP-lyase in Phaeocystis sp. (Prymnesiophyceae). Mar Ecol Prog Ser 131, 307-313.

Stefels, J., Dijkhuizen, L., and Gieskes, W. (1995). DMSP-lyase activity in a spring phytoplankton bloom off the Dutch coast, related to Phaeocystis sp. abundance. Mar Ecol Prog Ser 123, 235243.

Stefels, J. (2000). Physiological aspects of the production and conversion of DMSP in marine algae and higher plants. J Sea Res 43,183-197.

Stefels, J., Dijkhuizen, L., and Gieskes, W.W. (1995). DMSP-lyase activity in a spring phytoplankton bloom off the Dutch coast, related to Phaeocystis sp. abundance. Mar Ecol Prog Ser 123, 235-243.

Stefels, J., Steinke, M., Turner, S., Malin, G., and Belviso, S. (2007). Environmental constraints on the production and removal of the climatically active gas dimethylsulphide (DMS) and implications for ecosystem modelling. Biogeochemistry 83, 245-275.

Stefels, J., and van Boekel, W.H.M. (1993). Production of DMS from dissolved DMSP in axenic cultures of the marine phytoplankton species Phaeocystis sp. Mar Ecol Prog Ser 97, 11-18.

Stefels, J., van Leeuwe, M.A., Jones, E.M., Meredith, M.P., Venables, H.J., Webb, A.L., and Henley, S.F. (2018). Impact of sea-ice melt on dimethyl sulfide (sulfoniopropionate) inventories in surface waters of Marguerite Bay, West Antarctic Peninsula. Philos Trans A Math Phys Eng Sci 376, 20170169.

Steinke, M., Malin, G., Archer, S.D., Burkill, P.H., and Liss, P.S. (2002). DMS production in a coccolithophorid bloom: Evidence for the importance of dinoflagellate DMSP lyases. Aquat 
Microb Ecol 26, 259-270.

Steinke, M., Stefels, J., and Stamhuis, E. (2006). Dimethyl sulfide triggers search behavior in copepods. Limnol Oceanogr 51, 1925-1930.

Summers, P.S., Nolte, K.D., Cooper, A.J., Borgeas, H., Leustek, T., Rhodes, D., and Hanson, A.D. (1998). Identification and stereospecificity of the first three enzymes of 3dimethylsulfoniopropionate biosynthesis in a chlorophyte alga. Plant Physiol 116, 369-378.

Sun, J., Todd, J.D., Thrash, J.C., Qian, Y., Qian, M.C., Guo, J., Fowler, E.K., Aldrich, J.T., Nicora, C.D., Lipton, M.S., et al. (2016). The abundant marine bacterium Pelagibacter simultaneously catabolizes dimethylsulfoniopropionate to the gases dimethyl sulfide and methanethiol. Nat Microbiol 1, e16065

Sunda, W.G., Hardison, R., Kiene, R.P., Bucciarelli, E., and Harada, H. (2007). The effect of nitrogen limitation on cellular DMSP and DMS release in marine phytoplankton: climate feedback implications. Aquat Sci 69, 341-351.

Sunda, W., Kieber, D.J., Kiene, R.P., and Huntsman, S. (2002). An antioxidant function for DMSP and DMS in marine algae. Nature 418, 317-320.

Tan, T.T., Wu, X., Liu, C.Y., and Yang, G.P. (2017). Distributions of dimethylsulfide and its related compounds in the Yangtze (Changjiang) River Estuary and its adjacent waters in early summer. Cont Shelf Res 146, 89-101.

Tang, K.W., Rogers, D.R., Dam, H.G., and Visscher, P.T. (2000). Seasonal distribution of DMSP among seston, dissolved matter and zooplankton along a transect in the Long Island Sound estuary. Mar Ecol Prog Ser 206, 1-11.

Todd, J.D., Curson, A.R.J., Dupont, C.L., Nicholson, P., and Johnston, A.W.B. (2009). The $d d d P$ gene, encoding a novel enzyme that converts dimethylsulfoniopropionate into dimethyl sulfide, is widespread in ocean metagenomes and marine bacteria and also occurs in some Ascomycete fungi. Environ Microbiol 11, 1376-1385.

Todd, J.D., Curson, A.R.J., Kirkwood, M.M., Sullivan, J., Green, R.T., and Johnston, A.W.B. (2011). DddQ, a novel, cupin-containing, dimethylsulfoniopropionate lyase in marine roseobacters and in uncultured marine bacteria. Environ Microbiol 13, 427-438.

Todd, J.D., Curson, A.R.J., Nikolaidou-Katsaraidou, N., Brearley, C.A., Watmough, N.J., Chan, Y., Page, P.C.B., Sun, L., and Johnston, A.W.B. (2010). Molecular dissection of bacterial acrylate catabolism-unexpected links with dimethylsulfoniopropionate catabolism and dimethyl sulfide production. Environ Microbiol, 12, 327-343.

Todd, J.D., Kirkwood, M., Newton-Payne, S., and Johnston, A.W.B. (2012a). DddW, a third DMSP lyase in a model Roseobacter marine bacterium, Ruegeria pomeroyi DSS-3. ISME J 6, 223226.

Todd, J.D., Curson, A.R., Sullivan, M.J., Kirkwood, M., and Johnston, A.W.B. (2012b). The Ruegeria pomeroyi acuI gene has a role in DMSP catabolism and resembles $y h d H$ of $E$. coli and other bacteria in conferring resistance to acrylate. PLoS One 7, e35947.

Todd, J.D., Rogers, R., Li, Y.G., Wexler, M., Bond, P.L., Sun, L., Curson, A.R.J., Malin, G., Steinke, M., and Johnston, A.W.B. (2007). Structural and regulatory genes required to make the gas dimethyl sulfide in bacteria. Science 315, 666-669.

Tortell, P.D., Long, M.C., Payne, C.D., Alderkamp, A.C., Dutrieux, P., and Arrigo, K.R. (2012). Spatial distribution of pCO2, $\triangle \mathrm{O} 2 / \mathrm{Ar}$ and dimethylsulfide (DMS) in polynya waters and the sea ice zone of the Amundsen Sea, Antarctica. Deep Sea Res Part 2 Top Stud Oceanogr 71, 7793.

Townsend, D.W., and Keller, M.D. (1996). Dimethylsulfide (DMS) and dimethylsulfoniopropionate (DMSP) in relation to phytoplankton in the Gulf of Maine. Mar Ecol Prog Ser 137, 229-241.

Tripp, H.J., Kitner, J.B., Schwalbach, M.S., Dacey, J.W.H., Wilhelm, L.J., and Giovannoni, S.J. (2008). SAR11 marine bacteria require exogenous reduced sulphur for growth. Nature 452, $741-744$.

Trossat, C., Nolte, K.D., and Hanson, A.D. (1996). Evidence that the pathway of dimethylsulfoniopropionate biosynthesis begins in the cytosol and ends in the chloroplast. Plant Physiol 111, 965-973.

Trossat, C., Rathinasabapathi, B., Weretilnyk, E.A., Shen, T.L., Huang, Z.H., Gage, D.A., and Hanson, A.D. (1998). Salinity promotes accumulation of 3-dimethylsulfoniopropionate and its 
precursor $S$-methylmethionine in chloroplasts. Plant Physiol 116, 165-171.

Turner, S.M., Malin, G., and Liss, P.S. (1989). Dimethyl sulphide and dimethylsulphoniopropionate in European coastal and shelf waters. In: Biogenic Sulfur in the Environment (American Chemical Society), pp. 183-200.

Turner, S.M., Malin, G., Liss, P.S., Harbour, D.S., and Holligan, P.M. (1988). The seasonal variation of dimethyl sulfide and dimethylsulfoniopropionate concentrations in nearshore waters. Limnol Oceanogr 33, 364-375.

Turner, S.M., Nightingale, P.D., Broadgate, W., and Liss, P.S. (1995) The distribution of dimethyl sulphide and dimethylsulphoniopropionate in Antarctic waters and sea ice. Deep Sea Res Part 2 Top Stud Oceanogr 42, 1059-1080.

Uchida, A., Ooguri, T., Ishida, T., and Ishida, Y. (1992). Seasonal variations in dimethylsulfide in the water of Maizuru Bay. Nippon Suisan Gakkaishi 58, 255-259.

Uchida, A., Ooguri, T., Ishida, T., and Ishida, Y. (1993). Incorporation of methionine into dimethylthiopropanoic acid in the dinoflagellate Crypthecodinium cohnii. Bull Jap Soc Sci Fish, 59, 851-855.

Uchida, A., Ooguri, T., Ishida, T., Kitaguchi, H., and Ishida, Y. (1996). Biosynthesis of dimethylsulfoniopropionate in Crypthecodinium Cohnii (Dinophyceae). In: Biological and Environmental Chemistry of DMSP and Related Sulfonium Compounds (Boston MA: Springer).

Vairavamurthy, A., Andreae, M.O., and Iverson, R.L. (1985). Biosynthesis of dimethylsulfide and dimethylpropiothetin by Hymenomonas carterae in relation to sulfur source and salinity variations. Limnol Oceanogr 30, 59-70.

Vallina, S.M., and Simó, R. (2007). Strong relationship between DMS and the solar radiation dose over the global surface ocean. Science 315, 506-508.

Van Alstyne, K.L., and Puglisi, M.P. (2007). DMSP in marine macroalgae and macroinvertebrates: distribution, function, and ecological impacts. Aquat Sci 69, 394-402.

Van Alstyne, K.L., Wolfe, G.V., Freidenburg, T.L., Neill, A. and Hicken, C. (2001). Activated defense systems in marine macroalgae: Evidence for an ecological role for DMSP cleavage. Mar Ecol Prog Ser 213, 53-65.

Van der Maarel, M.J., and Hansen, T.A. (1996). Anaerobic microorganism involved in the degradation of DMS(P). In: Biological and Environmental Chemistry of DMSP and Related Sulfonium Compounds (Boston MA: Springer), pp. 351-360.

Vila, M., Simó, R., Kiene, R.P., Pinhassi, J., González, J.M., Moran, M.A., and Pedrós-Alió, C. (2004). Use of microautoradiography combined with fluorescence in situ hybridization to determine dimethylsulfoniopropionate incorporation by marine bacterioplankton taxa. Appl Environ Microbiol 70, 4648-4657.

Viswanadham, R., Bharathi, M.D., and Sarma, V.V.S.S. (2016). Variations in concentrations and fluxes of dimethylsulfide (DMS) from the Indian estuaries. Estuar Coast 39, 695-706.

Wagner, C., and Stadtman, E.R. (1962) Bacterial fermentation of dimethyl- $\beta$-propiothetin. Arch Biochem Biophys 98, 331-336.

Wang, P., Chen, X.L., Li, C.Y., Gao, X., Zhu, D.Y., Xie, B.B., Qin, Q.L., Zhang, X.Y., Su, H.N., Zhou, B.C., et al. (2015). Structural and molecular basis for the novel catalytic mechanism and evolution of DddP, an abundant peptidase-like bacterial dimethylsulfoniopropionate lyase: a new enzyme from an old fold. Mol Microbiol 98, 289-301.

Wolfe, G.V., and Steinke, M. (1996). Grazing-activated production of dimethyl sulfide (DMS) by two clones of Emiliania huxleyi. Limnol Oceanogr 41, 1151-1160.

Wolfe, G.V., Steinke, M., and Kirst, G.O. (1997). Grazing-activated chemical defence in a unicellular marine alga. Nature 387, 894.

Yang, G.-P., Jing, W.-W., Li, L., Kang, Z.-Q., and Song, G.-S. (2006). Distribution of dimethylsulfide and dimethylsulfoniopropionate in the surface microlayer and subsurface water of the Yellow Sea, China during spring. J Mar Syst 62, 22-34.

Yang, G.-P., Levasseur, M., Michaud, S., Merzouk, A., Lizotte, M., and Scarratt, M. (2009). Distribution of dimethylsulfide and dimethylsulfoniopropionate and its relation with phytoneuston in the surface microlayer of the western North Atlantic during summer. Biogeochemistry 94, 243-254. 
Yang, G.-P., Tsunogai, S., and Watanabe, S. (2005). Biogeochemistry of dimethylsulfoniopropionate (DMSP) in the surface microlayer and subsurface seawater of Funka Bay, Japan. J Oceanogr $61,69-78$.

Yang, G.-P., Zhang, H.-H., Zhou, L.-M., and Yang, J. (2011). Temporal and spatial variations of dimethylsulfide (DMS) and dimethylsulfoniopropionate (DMSP) in the East China Sea and the Yellow Sea. Cont Shelf Res 31, 1325-1335.

Yang, G.-P., Zhang, S.-H., Zhang, H.-H., Yang, J., and Liu, C.-Y. (2015). Distribution of biogenic sulfur in the Bohai Sea and northern Yellow Sea and its contribution to atmospheric sulfate aerosol in the late fall. Mar Chem 169, 23-32.

Yang, G.-P., Zhuang, G.-C., Zhang, H.-H., Dong, Y., and Yang, J. (2012). Distribution of dimethylsulfide and dimethylsulfoniopropionate in the Yellow Sea and the East China Sea during spring: spatio-temporal variability and controlling factors. Mar Chem 138, 21-31.

Yoch, D.C., Carraway, R.H., Friedman, R., and Kulkarni, N. (2001). Dimethylsulfide (DMS) production from dimethylsulfoniopropionate by freshwater river sediments: Phylogeny of Gram-positive DMS-producing isolates. FEMS Microbiol Ecol 37, 31-37.

Yoch, D.C. (2002). Dimethylsulfoniopropionate: Its Sources, role in the marine food web, and biological degradation to dimethylsulfide. Appl Environ Microbiol 68, 5804-5815.

Yost, D.M., and Mitchelmore, C.L. (2009). Dimethylsulfoniopropionate (DMSP) lyase activity in different strains of the symbiotic alga Symbiodinium microadriaticum. Mar Ecol Prog Ser 386, $61-70$.

Zhai, X., Zhang, H.-H., Yang, G.-P., Li, J.-L., and Yuan, D. (2018). Distribution and sea-air fluxes of biogenic gases and relationships with phytoplankton and nutrients in the central basin of the South China Sea during summer. Mar Chem 200, 33-44.

Zhang, H.-H., and Yang, G.-P. (2010). Distribution of dimethylsulfide (DMS) and dimethylsulphoniopropionate (DMSP) in the microlayer and subsurface water in Jiaozhou bay and Qingdao coastal water. Haiyang Yu Huzhao 41, 683-691.

Zhang, H.-H., Yang, G.-P., and Zhu, T. (2008). Distribution and cycling of dimethylsulfide (DMS) and dimethylsulfoniopropionate (DMSP) in the sea-surface microlayer of the Yellow Sea, China, in spring. Cont Shelf Res 28, 2417-2427.

Zhang, S.-H., Sun, J., Liu, J.-L., Wang, N., Zhang, H.-H., Zhang, X.-H., and Yang, G.-P. (2017). Spatial distributions of dimethyl sulfur compounds, DMSP-lyase activity, and phytoplankton community in the East China Sea during fall. Biogeochemistry 133, 59-72.

Zhang, S.-H., Yang, G.-P., Zhang, H.-H., and Yang, J. (2014). Spatial variation of biogenic sulfur in the south Yellow Sea and the East China Sea during summer and its contribution to atmospheric sulfate aerosol. Sci Total Environ 488, 157-167.

Zubkov, M.V., Fuchs, B.M., Archer, S.D., Kiene, R.P., Amann, R., and Burkill, P.-H. (2001). Linking the composition of bacterioplankton to rapid turnover of dissolved dimethylsulphoniopropionate in an algal bloom in the North Sea. Environ Microbiol 3, 304311. 
Table 1 The distribution of DMS and DMSP in typical sea areas reported in the literature

\begin{tabular}{|c|c|c|c|c|c|c|c|c|c|c|c|}
\hline Sea areas & Longitude & Latitude & Sampling time & $\begin{array}{l}\text { Station } \\
\text { numbers }\end{array}$ & $\mathrm{T}\left({ }^{\circ} \mathrm{C}\right)^{*}$ & $\begin{array}{l}\text { Sampling } \\
\text { depth }(\mathrm{m})\end{array}$ & DMS (nM) & $\begin{array}{l}\text { DMSPd } \\
(\mathrm{nM})\end{array}$ & $\begin{array}{l}\text { DMSPp } \\
(\mathrm{nM})\end{array}$ & $\begin{array}{l}\text { DMSPt } \\
(\mathrm{nM})\end{array}$ & Reference \\
\hline \multicolumn{12}{|c|}{ SAMPLING STATIONS WITH POINT RECORDS } \\
\hline Western Mediterranean & $\begin{array}{l}0^{\circ} 00^{\prime} \mathrm{E}- \\
06^{\circ} 20^{\prime} \mathrm{E}\end{array}$ & $\begin{array}{l}43^{\circ} 50^{\prime} \mathrm{N}- \\
38^{\circ} 00^{\prime} \mathrm{N}\end{array}$ & $\begin{array}{l}1 \quad \text { Jun.-2 } \\
\text { Aug., 1993 } \\
\text { 26-28 Apr. \& 15- } \\
\text { 21 Jul., } 1994\end{array}$ & 54 & N.D. & $0-200$ & $0-19.3$ & $0.1-18.3$ & N.D. & N.D. & $\begin{array}{l}\text { Simo et al., } \\
1997\end{array}$ \\
\hline Belgian Coastal Zone & $\begin{array}{l}02^{\circ} 30^{\prime} \mathrm{E}- \\
03^{\circ} 10^{\prime} \mathrm{E}\end{array}$ & $\begin{array}{l}51^{\circ} 48^{\prime} \mathrm{N}- \\
51^{\circ} 18^{\prime} \mathrm{N}\end{array}$ & Jan.-Dec., 2016 & 9 & $6.9-19.8$ & 3 & $0-269.7$ & N.D. -39.3 & $\begin{array}{l}\text { N.D.- } \\
1740.0\end{array}$ & $\begin{array}{l}\text { N.D.- } \\
1779.3 \S\end{array}$ & Speeckaert et al., 2018 \\
\hline The northern North Sea & $\begin{array}{l}02^{\circ} 30^{\prime} \mathrm{E}- \\
03^{\circ} 33^{\prime} \mathrm{E}\end{array}$ & $\begin{array}{l}58^{\circ} 52^{\prime} \mathrm{N}- \\
58^{\circ} 15^{\prime} \mathrm{N}\end{array}$ & 18-28 Jun., 1999 & 8 & $11.2-12.3$ & $5-11$ & $3.7-10.1$ & $\begin{array}{l}54.0- \\
121.0\end{array}$ & $4.4-16.4$ & $58.4-137.4 \S$ & Archer et al., 2001 \\
\hline $\begin{array}{l}\text { The Gulf of Lion (the } \\
\text { Mediterranean Sea) }\end{array}$ & $03^{\circ} 40^{\prime} \mathrm{E}$ & $42^{\circ} 20^{\prime} \mathrm{N}$ & Apr., 1990 & N.D. & N.D. & 15 & \multicolumn{2}{|c|}{$\begin{array}{c}9.24-14.3 \\
(\mathrm{DMS}+\mathrm{DMSPd})\end{array}$} & $31.9-39.0$ & N.D. & Belviso et al., 1993 \\
\hline $\begin{array}{l}\text { The Central Ligurian Sea } \\
\text { (the Mediterranean Sea) }\end{array}$ & $07^{\circ} 52^{\prime} \mathrm{E}$ & $43^{\circ} 24^{\prime} \mathrm{N}$ & 16-22 May, 1990 & N.D. & N.D. & 15 & $4.19-5.01$ & $2.8-6.8$ & $24.8-30.2$ & $\sim 32.3 \S$ & Belviso et al., 1993 \\
\hline \multirow[t]{2}{*}{ North Aegean Sea (Greece) } & $\begin{array}{l}24^{\circ} 51^{\prime} \mathrm{E}- \\
25^{\circ} 52^{\prime} \mathrm{E}\end{array}$ & $\begin{array}{l}40^{\circ} 51^{\prime} \mathrm{N}- \\
39^{\circ} 41^{\prime} \mathrm{N}\end{array}$ & Sep., 2003 & 11 & $15.8-25.2$ & $0-20$ & N.D. & $11.6-19.4$ & N.D. & $16.4-30.0$ & Mara et al., 2015 \\
\hline & $\begin{array}{l}24^{\circ} 03^{\prime} \mathrm{E}- \\
25^{\circ} 52^{\prime} \mathrm{E}\end{array}$ & $\begin{array}{l}40^{\circ} 51^{\prime} \mathrm{N}- \\
39^{\circ} 41^{\prime} \mathrm{N}\end{array}$ & Jul., 2004 & 10 & $14.6-24.5$ & $0-20$ & N.D. & $8.4-20.2$ & N.D. & $15.4-31.4$ & Mara et al., 2015 \\
\hline Barents Sea (Russia) & $\begin{array}{l}30^{\circ} 21^{\prime} \mathrm{E}- \\
32^{\circ} 56^{\prime} \mathrm{E}\end{array}$ & $\begin{array}{l}76^{\circ} 32^{\prime} \mathrm{N}- \\
72^{\circ} 45^{\prime} \mathrm{N}\end{array}$ & 13-29 May, 1993 & 4 & N.D. & $20-200$ & $2.8-25.3$ & $4.0-36.0$ & $6.0-27.0$ & $10.0-63.0 \S$ & Matrai et al., 1997 \\
\hline Western Indian Ocean & $\begin{array}{l}50^{\circ} 00^{\prime} \mathrm{E}- \\
77^{\circ} 00^{\prime} \mathrm{E}\end{array}$ & $\begin{array}{l}24^{\circ} 00^{\prime} \mathrm{S}- \\
49^{\circ} 00^{\prime} \mathrm{S}\end{array}$ & 3-20 Dec., 1997 & N.D. & N.D. & 8 & $0.9-35.8$ & N.D. & N.D. & N.D. & Sciare et al., 1999 \\
\hline $\begin{array}{l}\text { The Southern Ocean } \\
\text { (Australasian sector) }\end{array}$ & $\begin{array}{l}60^{\circ} 00^{\prime} \mathrm{E}- \\
160^{\circ} 00^{\prime} \mathrm{E}\end{array}$ & $\begin{array}{l}70^{\circ} 00^{\prime} \mathrm{S}- \\
40^{\circ} 00^{\prime} \mathrm{S}\end{array}$ & $\begin{array}{l}25 \text { Sep., 1991-8 } \\
\text { Dec., } 1995\end{array}$ & N.D. & N.D. & $0-4441$ & nd -22.0 & nd-71.0 & nd-102.0 & $\mathrm{nd}-173.0 \S$ & Curran et al., 1998 \\
\hline $\begin{array}{l}\text { The Southern Ocean (Indian } \\
\text { sector) }\end{array}$ & $\begin{array}{l}71^{\circ} 00^{\prime} \mathrm{E}- \\
79^{\circ} 00^{\prime} \mathrm{E}\end{array}$ & $\begin{array}{l}49^{\circ} 00^{\prime} \mathrm{S}- \\
53^{\circ} 50 ’ \mathrm{~S}\end{array}$ & $\begin{array}{l}19 \text { Jan.-13 Feb., } \\
2005\end{array}$ & 18 & 3 & $0-150$ & $0.2-0.8$ & N.D. & $5.0-20.0$ & N.D. & Belviso et al., 2008 \\
\hline Indian Estuaries (India) & $\begin{array}{l}72^{\circ} 00^{\prime} \mathrm{E}- \\
88^{\circ} 00^{\prime} \mathrm{E}\end{array}$ & $\begin{array}{l}23^{\circ} 00^{\prime} \mathrm{N}- \\
09^{\circ} 00^{\prime} \mathrm{N}\end{array}$ & $\begin{array}{l}28 \text { Jul.-18 Aug., } \\
2011 \text { \& 2-15 Jan., } \\
2012\end{array}$ & 25 & N.D. & $0-5$ & $0.1-38.3$ & N.D. & N.D. & N.D. & Viswanadham et al., 2016 \\
\hline
\end{tabular}




\begin{tabular}{|c|c|c|c|c|c|c|c|c|c|c|c|}
\hline $\begin{array}{l}\text { Coastal Bay of Bengal } \\
\text { (Northeastern part of the } \\
\text { Indian Ocean) }\end{array}$ & $\begin{array}{l}81^{\circ} 00^{\prime} \mathrm{E}- \\
87^{\circ} 40^{\prime} \mathrm{E}\end{array}$ & $\begin{array}{l}20^{\circ} 20^{\prime} \mathrm{N}- \\
15^{\circ} 30^{\prime} \mathrm{N}\end{array}$ & $\begin{array}{l}23 \text { Jul.-10 Aug., } \\
2010\end{array}$ & 71 & $26.8-29.9$ & N.D. & $1.2-28.2$ & N.D. & N.D. & $0.8-61.6$ & Rao et al., 2015 \\
\hline $\begin{array}{l}\text { Bohai Sea and Northern } \\
\text { Yellow Sea (China) }\end{array}$ & $\begin{array}{l}112^{\circ} 00^{\prime} \mathrm{E}- \\
124^{\circ} 06^{\prime} \mathrm{E}\end{array}$ & $\begin{array}{l}39^{\circ} 29^{\prime} \mathrm{N}- \\
17^{\circ} 43^{\prime} \mathrm{N}\end{array}$ & $\begin{array}{l}21 \text { Nov.-1 Dec., } \\
2011\end{array}$ & 40 & $\begin{array}{l}10.49- \\
15.77\end{array}$ & $16-77$ & $0.8-6.7$ & $0.9-12.9$ & $7.6-42.3$ & $9.0-45.2 \S$ & Yang et al., 2015 \\
\hline South China Sea (China) & $\begin{array}{l}113^{\circ} 50^{\prime} \mathrm{E}- \\
119^{\circ} 08^{\prime} \mathrm{E}\end{array}$ & $\begin{array}{l}17^{\circ} 00^{\prime} \mathrm{N}- \\
14^{\circ} 00^{\prime} \mathrm{N}\end{array}$ & $\begin{array}{l}20 \text { May-17 Jul., } \\
2014\end{array}$ & 19 & $\begin{array}{l}29.25- \\
30.66\end{array}$ & $1020-5112$ & $0.2-4.3$ & $0.1-3.3$ & $0.1-6.9$ & $1.0-7.9$ & Zhai et al., 2018 \\
\hline Antarctic Sea Ice & $\begin{array}{l}115^{\circ} 00^{\prime} \mathrm{E}- \\
125^{\circ} 00^{\prime} \mathrm{E}\end{array}$ & $\begin{array}{l}64^{\circ} 00^{\prime} \mathrm{S}- \\
66^{\circ} 00^{\prime} \mathrm{S}\end{array}$ & $\begin{array}{l}27 \text { Sep.-31 Oct., } \\
2012\end{array}$ & 18 & $\begin{array}{l}-22- \\
-3.6\end{array}$ & $0.14-1.5$ & N.D. & N.D. & N.D. & $0.5-750.0$ & Damm et al., 2016 \\
\hline $\begin{array}{l}\text { Yellow Sea and East China } \\
\text { Sea }\end{array}$ & $\begin{array}{l}119^{\circ} 50^{\prime} \mathrm{E}- \\
128^{\circ} 59^{\prime} \mathrm{E}\end{array}$ & $\begin{array}{l}38^{\circ} 48^{\prime} \mathrm{N}- \\
25^{\circ} 41^{\prime} \mathrm{N}\end{array}$ & $\begin{array}{l}26 \text { Apr.-21 May, } \\
2009\end{array}$ & 64 & $10-26$ & $15-946$ & $1.2-12.6$ & N.D. & N.D. & $5.5-73.7$ & Yang et al., 2012 \\
\hline $\begin{array}{l}\text { Yellow Sea and East China } \\
\text { Sea }\end{array}$ & $\begin{array}{l}119^{\circ} 57.840 \\
\mathrm{E}- \\
127^{\circ} 16.29 \\
1^{\prime} \mathrm{E}\end{array}$ & $\begin{array}{l}34^{\circ} 59.924 \\
\mathrm{~N}_{-} \\
25^{\circ} 11.064 \\
{ }^{\circ} \mathrm{N}\end{array}$ & $\begin{array}{l}28 \text { Jun.-15 Jul., } \\
2006 \\
22 \text { Jan.-13 Feb., } \\
2007\end{array}$ & $\begin{array}{l}35 \\
\text { (summer), } \\
53 \\
\text { (winter) }\end{array}$ & $\begin{array}{l}17.9-29.6 \\
\text { (summer) } \\
6.3-24.0 \\
\text { (winter) }\end{array}$ & $\begin{array}{l}1.6-2.7 \\
\text { (summer) } \\
15-1770 \\
\text { (winter) }\end{array}$ & $\begin{array}{l}1.8-12.2 \\
\text { (summer) } \\
1.0-3.5 \\
\text { (winter) }\end{array}$ & N.D. & N.D. & $\begin{array}{l}14.0-45.0 \\
\text { (summer) } \\
6.5-18.0 \\
\text { (winter) }\end{array}$ & Yang et al., 2011 \\
\hline Jiaozhou Bay (China) & $\begin{array}{l}120.18^{\circ} \mathrm{E}- \\
120.91^{\circ} \mathrm{E}\end{array}$ & $\begin{array}{l}36.12^{\circ} \mathrm{N}- \\
35.80^{\circ} \mathrm{N}\end{array}$ & 19-21 May., 2006 & 14 & N.D. & 0.2 & $2.6-7.7$ & $6.3-27.6$ & $7.2-31.5$ & $13.5-59.1 \S$ & Zhang et al. 2010 \\
\hline Yellow Sea (China) & $\begin{array}{l}121^{\circ} 00^{\prime} \mathrm{E}- \\
124^{\circ} 00^{\prime} \mathrm{E}\end{array}$ & $\begin{array}{l}39^{\circ} 00^{\prime} \mathrm{N}- \\
33^{\circ} 00^{\prime} \mathrm{N}\end{array}$ & Mar., 2005 & 21 & $2.81-9.50$ & $19-75$ & $0.99-5.10$ & $2.13-13.3$ & $4.89-40.1$ & N.D. & Yang et al., 2006 \\
\hline Yellow Sea (China) & $\begin{array}{l}121^{\circ} 14^{\prime} \mathrm{E}- \\
124^{\circ} 00^{\prime} \mathrm{E}\end{array}$ & $\begin{array}{l}39^{\circ} 10^{\prime} \mathrm{N}- \\
32^{\circ} 30^{\prime} \mathrm{N}\end{array}$ & Apr., 2006 & 43 & $4.5-13.74$ & $20-88.5$ & $1.7-12.8$ & $2.9-38.8$ & $4.3-36.1$ & $7.2-74.9 \S$ & Zhang et al., 2008 \\
\hline $\begin{array}{l}\text { East Yellow Sea and South } \\
\text { China Sea (China) }\end{array}$ & $\begin{array}{l}121^{\circ} 22^{\prime} \mathrm{E}- \\
127^{\circ} 19^{\prime} \mathrm{E}\end{array}$ & $\begin{array}{l}36^{\circ} 54^{\prime} \mathrm{N}- \\
27^{\circ} 30^{\prime} \mathrm{N}\end{array}$ & 5-26 Jul., 2011 & 60 & $\begin{array}{l}17.85- \\
28.62\end{array}$ & $20.7-1377$ & $0.6-41.2$ & $1.4-27.2$ & $6.2-207.7$ & 7.6-234.9 & Zhang et al., 2014 \\
\hline East China Sea (China) & $\begin{array}{l}121^{\circ} 40^{\prime} \mathrm{E}- \\
127^{\circ} 20^{\prime} \mathrm{E}\end{array}$ & $\begin{array}{l}31^{\circ} 83^{\prime} \mathrm{N}- \\
26^{\circ} 20^{\prime} \mathrm{N}\end{array}$ & $\begin{array}{l}19 \text { Oct. }-2 \text { Nov., } \\
2015\end{array}$ & 22 & $19.7-25.9$ & $31-1014$ & $1.0-9.6$ & $1.7-7.2$ & $5.6-83.8$ & $7.4-91.0 \S$ & Zhang et al., 2017 \\
\hline $\begin{array}{l}\text { Chang Jiang River Estuary } \\
\text { (China) }\end{array}$ & $\begin{array}{l}122^{\circ} 00^{\prime} \mathrm{E}- \\
124^{\circ} 30^{\prime} \mathrm{E}\end{array}$ & $\begin{array}{l}33^{\circ} 20^{\prime} \mathrm{N}- \\
27^{\circ} 50^{\prime} \mathrm{N}\end{array}$ & 7-14 Jun., 2014 & 32 & $\begin{array}{l}19.67- \\
24.86\end{array}$ & SW & $2.2-27.5$ & N.D. & N.D. & $5.9-195.0$ & Tan et al., 2017 \\
\hline Maizuru Bay (Japan) & $135^{\circ} 20^{\prime} \mathrm{E}$ & $35^{\circ} 27^{\prime} \mathrm{N}$ & $\begin{array}{l}\text { May, 1986-Apr., } \\
1987\end{array}$ & 5 & N.D. & N.D. & $0.64-289.7$ & N.D. & N.D. & N.D. & Uchida et al., 1992 \\
\hline Funka Bay (Japan) & $\begin{array}{l}140^{\circ} 50^{\prime} \mathrm{E}- \\
141^{\circ} 00^{\prime} \mathrm{E}\end{array}$ & $\begin{array}{l}42^{\circ} 60^{\prime} \mathrm{N}- \\
42^{\circ} 00^{\prime} \mathrm{N}\end{array}$ & $\begin{array}{l}23 \text { Oct., 2000-9 } \\
\text { Mar., } 2001\end{array}$ & 28 & $1.11-16.16$ & SM \& SW & N.D. & $2.1-48.6$ & $3.8-202.6$ & $19.7-300.7 \S$ & Yang et al., 2005 \\
\hline
\end{tabular}




\begin{tabular}{|c|c|c|c|c|c|c|c|c|c|c|c|}
\hline The Subarctic North Pacific & $\begin{array}{l}148^{\circ} 00^{\prime} \mathrm{E}- \\
140^{\circ} 00 \mathrm{~W}\end{array}$ & $\begin{array}{l}57^{\circ} 40^{\prime} \mathrm{N}- \\
42^{\circ} 00^{\prime} \mathrm{N}\end{array}$ & $\begin{array}{l}14 \text { Jul.-5 Sep., } \\
1997\end{array}$ & 21 & N.D. & $10-100$ & $1.3-13.2$ & N.D. & N.D. & N.D. & Aranami et al., 2001 \\
\hline $\begin{array}{lll}\text { Ross Sea } & \text { (the bay of } \\
\text { Southern } & \text { Ocean } & \text { in } \\
\text { Antarctica) } & & \end{array}$ & $\begin{array}{l}167^{\circ} 00^{\prime} \mathrm{E}- \\
179^{\circ} 10 \mathrm{~W} \square\end{array}$ & $\begin{array}{l}74^{\circ} 50^{\prime} \mathrm{S}- \\
78^{\circ} 00^{\prime} \mathrm{S}\end{array}$ & $\begin{array}{l}31 \text { Dec., } 2004-21 \\
\text { Jan., } 2005 \\
\& \quad 10-30 \text { Nov., } \\
2005\end{array}$ & 8 & $-2.1-1.6$ & $390-740$ & $0.1-23.0$ & N.D. & N.D. & $0.5-78.0$ & Rellinger et al., 2009 \\
\hline $\begin{array}{l}\text { The Southern Ocean } \\
\text { (Near south of New Zealand) }\end{array}$ & $\begin{array}{l}170^{\circ} 00^{\prime} \mathrm{E}- \\
180^{\circ} 00^{\prime} \mathrm{E}\end{array}$ & $\begin{array}{l}49^{\circ} 00^{\prime} \mathrm{S}- \\
76^{\circ} 50^{\prime} \mathrm{S}\end{array}$ & $\begin{array}{l}31 \text { Oct.-16 Nov., } \\
2003 \& \& \quad 20-28 \\
\text { Dec., 2004 \& } 28 \\
\text { Oct.-8 Nov.,2005 }\end{array}$ & $>55$ & $0-7$ & 4 & $0.6-30.0$ & N.D. & N.D. & $1.0-118.0$ & Kiene et al., 2007 \\
\hline North Pacific Ocean & $\begin{array}{l}177^{\circ} 48^{\prime} \mathrm{E}- \\
146^{\circ} 31^{\prime} \mathrm{W}\end{array}$ & $\begin{array}{l}23^{\circ} 06^{\prime} \mathrm{N}- \\
08^{\circ} 25^{\prime} \mathrm{N}\end{array}$ & $\begin{array}{ll}\text { 12-28 Dec., } & 2011 \\
\& \quad 16-18 & \text { Feb., } \\
2012 & \end{array}$ & 8 & $\begin{array}{l}25.35- \\
26.82\end{array}$ & 5 & $3.2-5.3$ & $0.5-1.0$ & $6.0-8.8$ & $7.0-9.5$ & Cui et al., 2015 \\
\hline Northeast Pacific Ocean & $\begin{array}{l}126^{\circ} 10^{\prime} \mathrm{W}- \\
124^{\circ} 10^{\prime} \mathrm{W}\end{array}$ & $\begin{array}{l}48^{\circ} 40^{\prime} \mathrm{N}- \\
44^{\circ} 50^{\prime} \mathrm{N}\end{array}$ & 14-18 May, 1985 & N.D. & 20 & N.D. & $0.6-2.8$ & N.D. & N.D. & N.D. & Andreae et al., 1988 \\
\hline Equatorial Pacific Ocean & $\begin{array}{l}124^{\circ} 39^{\prime} \mathrm{W}- \\
115^{\circ} 00^{\prime} \mathrm{W}\end{array}$ & $\begin{array}{l}0^{\circ} 30^{\prime} \mathrm{N}- \\
0^{\circ} 00^{\prime} \mathrm{S}\end{array}$ & 7-10 Feb., 2012 & 5 & $\begin{array}{l}23.86- \\
26.73\end{array}$ & 5 & $2.4-5.8$ & $2.1-6.8$ & $14.8-20.2$ & $21.6-25.2$ & Cui et al., 2015 \\
\hline South Pacific Ocean & $\begin{array}{l}120^{\circ} 00^{\prime} \mathrm{W}- \\
84^{\circ} 52^{\prime} \mathrm{W}\end{array}$ & $\begin{array}{l}14^{\circ} 45^{\prime} \mathrm{S}_{-} \\
22^{\circ} 31^{\prime} \mathrm{S}\end{array}$ & 6-24 Jan., 2012 & 7 & $\begin{array}{l}24.04- \\
25.82\end{array}$ & 5 & $3.2-6.3$ & N.D. & N.D. & N.D. & Cui et al., 2015 \\
\hline Amundsen Sea & $\begin{array}{l}118^{\circ} 00^{\prime} \mathrm{W}- \\
101^{\circ} 40^{\prime} \mathrm{W}\end{array}$ & $\begin{array}{l}70^{\circ} 20^{\prime} \mathrm{S}- \\
74^{\circ} 57^{\prime} \mathrm{S}\end{array}$ & $\begin{array}{l}11 \text { Jan.-16 Feb., } \\
2009\end{array}$ & 51 & $-1.8-1.9$ & $9-160$ & $<1-350$ & N.D. & N.D. & N.D. & Tortell et al., 2012 \\
\hline $\begin{array}{l}\text { Canadian Subarctic and } \\
\text { Arctic Marine }\end{array}$ & $\begin{array}{l}100.69^{\circ} \mathrm{W}- \\
53.37^{\circ} \mathrm{W}\end{array}$ & $\begin{array}{l}74.75^{\circ} \mathrm{N}- \\
56.12^{\circ} \mathrm{N}\end{array}$ & $\begin{array}{l}10 \text { Jul.-20 Aug., } \\
2015 .\end{array}$ & 9 & $-2-8$ & $2.1-41.4$ & $\sim 1.0-18.0$ & N.D. & N.D. & $10.6-38.2$ & Jarníková et al., 2018 \\
\hline $\begin{array}{l}\text { Northern Gulf of Mexico } \\
\text { (American) }\end{array}$ & $\begin{array}{l}92^{\circ} 00^{\prime} \mathrm{W}- \\
89^{\circ} 00^{\prime} \mathrm{W}\end{array}$ & $\begin{array}{l}30^{\circ} 00^{\prime} \mathrm{N}- \\
26^{\circ} 00^{\prime} \mathrm{N}\end{array}$ & 12-21 Sep., 2011 & 12 & $27.3-29.2$ & $1.4-30.6$ & $0.8-4.7$ & $0.8-2.9$ & $5.9-27.3$ & $8.6-29.0$ & Motard-Côté et al., 2016 \\
\hline $\begin{array}{l}\text { Northern Baffin Bay } \\
\text { (Lancaster Sound), Canadian }\end{array}$ & $\begin{array}{l}90^{\circ} 00^{\prime} \mathrm{W}- \\
64^{\circ} 50^{\prime} \mathrm{W}\end{array}$ & $\begin{array}{l}77^{\circ} 30^{\prime} \mathrm{N}- \\
70^{\circ} 50^{\prime} \mathrm{N}\end{array}$ & 7-27 Sep., 2008 & 14 & $-1.3-3.8$ & $2-4$ & $0.5-4.8$ & $0-2.1$ & $5.0-70.0$ & $5.5-71.7 \S$ & Motard-Côté et al., 2012 \\
\hline Ochlockonee Bay (America) & $\begin{array}{l}84^{\circ} 28^{\prime} \mathrm{W}- \\
84^{\circ} 15^{\prime} \mathrm{W}\end{array}$ & $\begin{array}{l}30^{\circ} 00^{\prime} \mathrm{N}- \\
29^{\circ} 56^{\prime} \mathrm{N}\end{array}$ & Sep., 1986 & 12 & N.D. & 3 & $1.8-14.0$ & $2.0-22.5$ & $4.0-42.0$ & $6.0-57.0 \S$ & Iverson et al., 1989 \\
\hline $\begin{array}{l}\text { Chesapeake Bay (including } \\
\text { the Potomac River) (USA) }\end{array}$ & $\begin{array}{l}77^{\circ} 20^{\prime} \mathrm{W}- \\
75^{\circ} 00^{\prime} \mathrm{W}\end{array}$ & $\begin{array}{l}39^{\circ} 00^{\prime} \mathrm{N}- \\
33^{\circ} 00^{\prime} \mathrm{N}\end{array}$ & Sep., 1986 & $>60$ & N.D. & 3 & $1.0-18.0$ & $0-18.0$ & $1.0-64.0$ & $1.0-68.0$ & Iverson et al., 1989 \\
\hline $\begin{array}{l}\text { Long Island Sound estuary } \\
\text { (America) }\end{array}$ & $72^{\circ} 06^{\prime} \mathrm{W}-$ & $41^{\circ} 20^{\prime} \mathrm{N}-$ & $\begin{array}{l}\text { Dec., 1998-Jan., } \\
2000\end{array}$ & 3 & $2-25$ & 0 & $0-3.0$ & $0-3.0$ & $1.0-49.0$ & $1.0-52.0$ & Tang et al., 2000 \\
\hline
\end{tabular}




\begin{tabular}{|c|c|c|c|c|c|c|c|c|c|c|c|}
\hline & $72^{\circ} 04^{\prime} \mathrm{W}$ & $41^{\circ} 18^{\prime} \mathrm{N}$ & & & & & & & & & \\
\hline $\begin{array}{l}\text { Marguerite Bay (West } \\
\text { Antarctic Peninsula) }\end{array}$ & $\begin{array}{l}71^{\circ} 20^{\prime} \mathrm{W}- \\
68^{\circ} 10^{\prime} \mathrm{W}\end{array}$ & $\begin{array}{l}66^{\circ} 50^{\prime} \mathrm{S}- \\
68^{\circ} 30^{\prime} \mathrm{S}\end{array}$ & 1-7 Jan., 2015 & 11 & $-1-0.5$ & $5-129$ & N.D. & $\begin{array}{l}12.0- \\
275.0 \S\end{array}$ & $\begin{array}{l}82.0- \\
368.0\end{array}$ & $94.0-643.0$ & Stefels et al., 2018 \\
\hline Gulf of Maine (Canada) & $\begin{array}{l}69^{\circ} 30^{\prime} \mathrm{W}- \\
68^{\circ} 20^{\prime} \mathrm{W}\end{array}$ & $\begin{array}{l}43^{\circ} 10^{\prime} \mathrm{N}- \\
41^{\circ} 00^{\prime} \mathrm{N}\end{array}$ & Jul., 1990 & 7 & N.D. & $0-100$ & $0.8-8.3$ & $0-175.0$ & $0-260.0$ & $1.3-368.0$ & Matrai et al., 1993 \\
\hline $\begin{array}{l}\text { Sargasso Sea (North Atlantic } \\
\text { Ocean) }\end{array}$ & $64^{\circ} 30^{\prime} \mathrm{W}$ & $32^{\circ} 10^{\prime} \mathrm{N}$ & $\begin{array}{l}\text { Jan., 1992-Dec., } \\
1993\end{array}$ & 1 & N.D. & $0-140$ & $0-12.0$ & $0-20.0$ & $0-27.0$ & $0-47.0 \S$ & $\begin{array}{l}\text { Dacey et al., } \\
1998\end{array}$ \\
\hline Northwest Atlantic & $\begin{array}{l}62^{\circ} 17^{\prime} \mathrm{W}- \\
41^{\circ} 00^{\prime} \mathrm{W}\end{array}$ & $\begin{array}{l}61^{\circ} 22^{\prime} \mathrm{N}- \\
38^{\circ} 00^{\prime} \mathrm{N}\end{array}$ & $\begin{array}{l}10 \text { Sep.-2Oct., } \\
1999\end{array}$ & 8 & $2.8-27.4$ & $6.3-7.4$ & $0.2-7.7$ & $1.9-54.3$ & $7.3-119.8$ & $10.1-203.0$ & $\begin{array}{l}\text { Scarratt et al., } 2007 \text { \& } \\
\text { Yang et al., } 2009\end{array}$ \\
\hline $\begin{array}{l}\text { Gulf of Saint Lawrence } \\
\text { (Canada) }\end{array}$ & $\begin{array}{l}60^{\circ} 00^{\prime} \mathrm{W}- \\
64^{\circ} 00^{\prime} \mathrm{W}\end{array}$ & $\begin{array}{l}49^{\circ} 00^{\prime} \mathrm{N}- \\
47^{\circ} 00^{\prime} \mathrm{N}\end{array}$ & 4-11 Aug., 1993 & 79 & $13-19$ & $0-100$ & $0-8.8$ & $1.7-23.1$ & $6.1-117.0$ & $7.8-140.1 \S$ & $\begin{array}{l}\text { Cantin et al., } \\
1996\end{array}$ \\
\hline Atlantic Ocean & $\begin{array}{l}60^{\circ} 00^{\prime} \mathrm{W}- \\
00^{\circ} 00^{\prime} \mathrm{W}\end{array}$ & $\begin{array}{l}40^{\circ} 00^{\prime} \mathrm{S}- \\
50^{\circ} 00^{\prime} \mathrm{N}\end{array}$ & Mar.-Apr., 1987 & 28 & N.D. & 10 & $0.1-10.0$ & N.D. & N.D. & $0-23.0$ & Burgermeister et al., 1990 \\
\hline Western North Atlantic & $\begin{array}{l}57^{\circ} 41.2^{\prime} \mathrm{W}- \\
45^{\circ} 00^{\prime} \mathrm{W}\end{array}$ & $\begin{array}{l}59^{\circ} 14.7^{\prime} \mathrm{N} \\
- \\
36^{\circ} 49.5^{\prime} \mathrm{N}\end{array}$ & 8-22 July, 2003 & 8 & $4.08-26.14$ & 1 & $0.2-7.6$ & $1.87-54.3$ & $7.3-119.8$ & N.D. & Yang et al., 2009 \\
\hline Antarctic Ocean & $\begin{array}{l}54^{\circ} 00^{\prime} \mathrm{W}- \\
87^{\circ} 00^{\prime} \mathrm{W}\end{array}$ & $\begin{array}{l}52^{\circ} 00^{\prime} \mathrm{S}- \\
71^{\circ} 00^{\prime} \mathrm{S}\end{array}$ & $\begin{array}{l}24 \text { Oct.-29 Dec., } \\
1992\end{array}$ & $>123$ & $-1.4-0.9$ & 3 & $0.2-27.0$ & $1.0-28.0$ & $2.0-69.0$ & N.D. & Turner et al., 1995 \\
\hline \multirow[t]{3}{*}{$\begin{array}{l}\text { The tropical Northeastern } \\
\text { Atlantic Ocean }\end{array}$} & $31^{\circ} 00^{\prime} \mathrm{W}$ & $21^{\circ} 00^{\prime} \mathrm{N}$ & $\begin{array}{l}\text { 21-22 Sep., } 1991 \\
\& 14 \text { Oct., } 1991\end{array}$ & 3 & N.D. & $0-150$ & $0.5-2.2$ & $2.0-14.4 \S$ & $0-37.0$ & $2.0-40.4 \S$ & Belviso et al., 1993 \\
\hline & $21^{\circ} 00^{\prime} \mathrm{W}$ & $18^{\circ} 30^{\prime} \mathrm{N}$ & 16-17 Sep., 1991 & 2 & N.D. & $0-100$ & $0.6-2.5$ & $1.0-9.3 \S$ & $0-39.0$ & $1.9-45.5 \S$ & \\
\hline & $21^{\circ} 00^{\prime} \mathrm{W}$ & $18^{\circ} 30^{\prime} \mathrm{N}$ & 6-7 Oct., 1991 & 3 & N.D. & $0-100$ & $2.3-7.6$ & $0-2.3 \S$ & $12.5-37.5$ & $14.8-18.2 \S$ & \\
\hline $\begin{array}{l}\text { Northeast Atlantic } \\
\text { (between UK and Iceland) }\end{array}$ & $\begin{array}{l}21^{\circ} 00^{\prime} \mathrm{W}- \\
0^{\circ} 00^{\prime} \mathrm{W}\end{array}$ & $\begin{array}{l}65^{\circ} 00^{\prime} \mathrm{N}- \\
54^{\circ} 00^{\prime} \mathrm{N}\end{array}$ & Jun.-Jul., 1987 & 158 & N.D. & 3 & $1.1-93.8$ & $\begin{array}{l}<1.3- \\
199.0\end{array}$ & $\begin{array}{l}10.8- \\
280.0\end{array}$ & $12.1-479.0 \S$ & $\begin{array}{l}\text { Malin et al., } \\
1993\end{array}$ \\
\hline The Western Coast of Ireland & $\begin{array}{l}15^{\circ} 00^{\prime} \mathrm{W}- \\
10^{\circ} 00^{\prime} \mathrm{W}\end{array}$ & $\begin{array}{l}55^{\circ} 00^{\prime} \mathrm{N}- \\
51^{\circ} 00^{\prime} \mathrm{N}\end{array}$ & $\begin{array}{l}26 \text { Jun. }-2 \text { Jul., } \\
1996\end{array}$ & $>350$ & N.D. & $3-200$ & $<0.2-42.0$ & $20.0-80.0$ & $\begin{array}{l}50.0- \\
635.0\end{array}$ & N.D. & Locarnini et al., 1998 \\
\hline Mediterranean Sea & $\begin{array}{l}10^{\circ} 00^{\prime} \mathrm{W}- \\
22^{\circ} 00^{\prime} \mathrm{E}\end{array}$ & $\begin{array}{l}38^{\circ} 00^{\prime} \mathrm{N}- \\
30^{\circ} 50^{\prime} \mathrm{N}\end{array}$ & 11-20 Sep., 1999 & $>61$ & N.D. & $3-5$ & $0.4-90.0$ & N.D. & N.D. & $20.0-300.0$ & Belviso et al., 2003 \\
\hline $\begin{array}{l}\text { Norwegian and Greenland } \\
\text { Seas }\end{array}$ & $\begin{array}{l}08^{\circ} 00^{\prime} \mathrm{W}- \\
10^{\circ} 00^{\prime} \mathrm{E}\end{array}$ & $\begin{array}{l}75^{\circ} 00^{\prime} \mathrm{N}- \\
66^{\circ} 00^{\prime} \mathrm{N}\end{array}$ & Jul.-Sep., 2012 & 17 & $5.74-11.64$ & $0-4000$ & $0.8-22.4$ & $0.4-43.3$ & $0.1-282.4$ & N.D. & Li et al., 2015 \\
\hline Southern Ocean (Atlantic & $06^{\circ} 00^{\prime} \mathrm{W}$ & $60^{\circ} 00^{\prime} \mathrm{S}_{-}$ & 29 Sep.-26 Nov., & 13 & N.D. & 20 & N.D. & $3.0-66.0$ & $3.0-61.0$ & $6.0-127.0 \S$ & Deyerdierks et al., 1997 \\
\hline
\end{tabular}




\begin{tabular}{|c|c|c|c|c|c|c|c|c|c|c|c|}
\hline sector) & & $47^{\circ} 00^{\prime} \mathrm{S}$ & 1992 & & & & & & & & \\
\hline \multicolumn{12}{|c|}{ SAMPLING STATIONS WITH DEPTH-PROFILE } \\
\hline \multirow[t]{3}{*}{$\begin{array}{l}\text { The Southern } \\
\text { (Australasia sector) }\end{array}$} & $\begin{array}{l}60^{\circ} 00^{\prime} \mathrm{E}- \\
160^{\circ} 00^{\prime} \mathrm{E}\end{array}$ & $\begin{array}{l}70^{\circ} 00^{\prime} \mathrm{S}_{-} \\
40^{\circ} 00^{\prime} \mathrm{S}\end{array}$ & $\begin{array}{l}25 \text { Sep.,1991-8 } \\
\text { Dec., } 1995\end{array}$ & N.D. & N.D. & $0-1000$ & $0.7-3.2$ & N.D. & N.D. & $0.7-2.4$ & Curran et al., 1998 \\
\hline & & & & & & $3000-4000$ & $1.1-4.0$ & N.D. & N.D. & N.D. & \\
\hline & & & & & & $4000-4441$ & $0.3-4.5$ & N.D. & N.D. & N.D. & \\
\hline \multirow[t]{3}{*}{ South China Sea } & $\begin{array}{l}113^{\circ} 50^{\prime} \mathrm{E}- \\
119^{\circ} 08^{\prime} \mathrm{E}\end{array}$ & $\begin{array}{l}17^{\circ} 00^{\prime} \mathrm{N}- \\
14^{\circ} 00^{\prime} \mathrm{N}\end{array}$ & $\begin{array}{l}20 \text { May-17 Jul., } \\
2014\end{array}$ & 19 & $\begin{array}{l}29.25- \\
30.64\end{array}$ & $1020-3000$ & $0.3-3.5$ & $0.1-3.3$ & $1.1-5.9$ & $1.2-9.2 \S$ & Zhai et al., 2018 \\
\hline & & & & & & $3000-4000$ & $0.2-1.5$ & $0.2-0.8$ & $1.0-3.2$ & $1.20-4.0 \S$ & \\
\hline & & & & & & $4000-5112$ & $0.2-4.3$ & $0.1-1.5$ & $0.1-6.9$ & $0.3-8.4 \S$ & \\
\hline \multirow[t]{9}{*}{$\begin{array}{l}\text { East China Sea and Yellow } \\
\text { Sea }\end{array}$} & $\begin{array}{l}119^{\circ} 58^{\prime} \mathrm{E}- \\
128^{\circ} 37^{\prime} \mathrm{E}\end{array}$ & $\begin{array}{l}35^{\circ} 00^{\prime} \mathrm{N}- \\
25^{\circ} 11^{\prime} \mathrm{N}\end{array}$ & $\begin{array}{l}22 \text { Jan.-13 Feb. } \\
2007\end{array}$ & 53 & $6.3-24$ & $15-100$ & $1.3-3.5(2.0)$ & N.D. & N.D. & $\begin{array}{l}7.1-18.0 \\
(12.1)\end{array}$ & Yang et al., 2011 \\
\hline & & & & & & $100-200$ & $1.1-2.6(1.8)$ & N.D. & N.D. & $\begin{array}{l}6.52-14.28 \\
(10.8)\end{array}$ & \\
\hline & & & & & & $400-500$ & 1.2 & N.D. & N.D. & 9.0 & \\
\hline & & & & & & $500-600$ & 1.2 & N.D. & N.D. & 6.7 & \\
\hline & & & & & & $600-700$ & 1.0 & N.D. & N.D. & 6.9 & \\
\hline & & & & & & $700-800$ & 1.4 & N.D. & N.D. & 9.0 & \\
\hline & & & & & & $800-900$ & $1.2-1.4(1.3)$ & N.D. & N.D. & $\begin{array}{l}7.3-8.7 \\
(8.0)\end{array}$ & \\
\hline & & & & & & $1000-1500$ & 1.3 & N.D. & N.D. & 7.6 & \\
\hline & & & & & & $1500-2000$ & 1.2 & N.D. & N.D. & 7.4 & \\
\hline \multirow[t]{4}{*}{$\begin{array}{l}\text { Norwegian and Greenland } \\
\text { Seas }\end{array}$} & $\begin{array}{l}05^{\circ} 00^{\prime} \mathrm{W}- \\
10^{\circ} 00^{\prime} \mathrm{E}\end{array}$ & $\begin{array}{l}75^{\circ} 00^{\prime} \mathrm{N}- \\
66^{\circ} 00^{\prime} \mathrm{N}\end{array}$ & Jul.-Sep.., 2012 & 17 & $0.0-7.5$ & $0-1000$ & $0.5-10.0$ & $0.5-20.0$ & $5-130.0 \S$ & $5.0-150.0$ & Li et al., 2015 \\
\hline & & & & & & $1000-2000$ & $0.5-3.0$ & $0-8.0$ & $0-12.0 \S$ & $0-20.0$ & \\
\hline & & & & & & $2000-3000$ & $0.5-5.0$ & $0-15.0$ & $0-5.0 \S$ & $0-20.0$ & \\
\hline & & & & & & $3000-4000$ & $0-3.0$ & $0-2.0$ & $0-10.0 \S$ & $0-10.0$ & \\
\hline
\end{tabular}

* Surface $(0-1 \mathrm{~m})$ seawater temperature. $\S$ values from calculation. N.D., no data. nd, nondetectable. SW, surface water; SM, surface microlayer. 
Table 2 Major representative DMSP-producing biological taxa

\begin{tabular}{|c|c|c|c|c|c|c|}
\hline $\begin{array}{l}\text { Taxonomic position } \\
\text { (phylum/class/family) }\end{array}$ & Species or Strain & $\begin{array}{l}\text { Biosynthesis } \\
\text { Pathway }\end{array}$ & $\begin{array}{l}\text { Key Enzyme \& } \\
\text { Peptide type }\end{array}$ & $\begin{array}{l}\text { Intracellular DMSP } \\
\text { Concentration }(\mathrm{mM})^{*}\end{array}$ & $\begin{array}{l}\text { DMSP } \\
\text { Production* }\end{array}$ & Reference \\
\hline \multicolumn{7}{|c|}{ ALGAE AND CORALS (EUKARYOTE) } \\
\hline \multirow[t]{2}{*}{$\begin{array}{l}\text { Haptophyta/Prymnesiophyce } \\
\text { ae/Chrysochromulinaceae }\end{array}$} & $\begin{array}{l}\text { Chrysochromulina tobin } \\
\text { CCMP291 }\end{array}$ & Transamination & $\begin{array}{l}\text { DSYB; MTHB } \\
\text { methyltransferase }\end{array}$ & $0.611 \pm 0.08$ & N.T. & Curson et al., 2018 \\
\hline & $\begin{array}{l}\text { Chrysochromulina sp. } \\
\text { PCC } 307\end{array}$ & Transamination & $\begin{array}{l}\text { DSYB; MTHB } \\
\text { methyltransferase }\end{array}$ & $0.196 \pm 0.0394$ & N.T. & Curson et al., 2018 \\
\hline \multirow[t]{6}{*}{$\begin{array}{l}\text { Haptophyta/Prymnesiophyce } \\
\text { ae/Prymnesiaceae }\end{array}$} & $\begin{array}{l}\text { Prymnesium parvum } \\
\text { CCAP946/6 }\end{array}$ & Transamination & $\begin{array}{l}\text { DSYB; MTHB } \\
\text { methyltransferase }\end{array}$ & $54.3 \pm 5.97$ & N.T. & Curson et al., 2018 \\
\hline & $\begin{array}{l}\text { Prymnesium parvum } \\
\text { CCAP941/6 }\end{array}$ & Transamination & $\begin{array}{l}\text { DSYB; MTHB } \\
\text { methyltransferase }\end{array}$ & $20.6 \pm 3.05$ & N.T. & Curson et al., 2018 \\
\hline & $\begin{array}{l}\text { Prymnesium parvum } \\
\text { CCAP946/1A }\end{array}$ & Transamination & $\begin{array}{l}\text { DSYB; MTHB } \\
\text { methyltransferase }\end{array}$ & $53.8 \pm 4.58$ & N.T. & Curson et al., 2018 \\
\hline & $\begin{array}{l}\text { Prymnesium parvum } \\
\text { CCAP946/1D }\end{array}$ & Transamination & $\begin{array}{l}\text { DSYB; MTHB } \\
\text { methyltransferase }\end{array}$ & $35.5 \pm 1.50$ & N.T. & Curson et al., 2018 \\
\hline & $\begin{array}{l}\text { Prymnesium parvum } \\
\text { CCAP946/1B }\end{array}$ & Transamination & $\begin{array}{l}\text { DSYB; MTHB } \\
\text { methyltransferase }\end{array}$ & $48.4 \pm 6.29$ & N.T. & Curson et al., 2018 \\
\hline & $\begin{array}{l}\text { Prymnesium patelliferum } \\
\text { CCAP } 946 / 4\end{array}$ & Transamination & $\begin{array}{l}\text { DSYB; MTHB } \\
\text { methyltransferase }\end{array}$ & $25.3 \pm 2.39$ & N.T. & Curson et al., 2018 \\
\hline $\begin{array}{l}\text { Haptophyta/Prymnesiophyce } \\
\text { ae/Hymenomonadaceae }\end{array}$ & Hymenomonas carterae & Unknown & Unknown & 120 & N.T. & $\begin{array}{l}\text { Vairavamurthey et al., } \\
1985\end{array}$ \\
\hline $\begin{array}{l}\text { Haptophyta/Prymnesiophyce } \\
\text { ae/Phaeocystaceae }\end{array}$ & Phaeocystis sp. & Unknown & Unknown & $71-169$ & N.T. & $\begin{array}{l}\text { Stefels and van Boekel, } \\
1993\end{array}$ \\
\hline $\begin{array}{l}\text { Haptophyta/Chrysophyceae/ } \\
\text { Chromulinaceae }\end{array}$ & Ochromonas sp. & Unknown & Unknown & 529 & N.T. & Keller et al., 1989 \\
\hline
\end{tabular}




\begin{tabular}{|c|c|c|c|c|c|c|}
\hline $\begin{array}{l}\text { Haptophyta/Coccolithophyce } \\
\text { ae/Noelaerhabdaceae }\end{array}$ & Emiliania huxleyi BT6 & Unknown & Unknown & 166 & N.T. & Keller et al., 1989 \\
\hline $\begin{array}{l}\text { Bacillariophyta/Bacillarioph } \\
\text { yceae/Bacillariaceae }\end{array}$ & $\begin{array}{l}\text { Fragilariopsis cylindrus } \\
\text { CCMP } 1102\end{array}$ & Transamination & $\begin{array}{l}\text { DSYB; MTHB } \\
\text { methyltransferase }\end{array}$ & $6.71 \pm 0.92$ & N.T. & $\begin{array}{l}\text { Lyon et al., 2011; Curson } \\
\text { et al., } 2018\end{array}$ \\
\hline $\begin{array}{l}\text { Bacillariophyta/Coscinodisc } \\
\text { ophyceae/Thalassiosiraceae }\end{array}$ & Thalassiosira pseudonana & Transamination & $\begin{array}{l}\text { TpMMT; MTHB } \\
\text { methyltransferase }\end{array}$ & $\sim 20-30$ & $\begin{array}{l}\sim 1 \mu \mathrm{mol} / \mathrm{g} \\
\text { fresh mass }\end{array}$ & $\begin{array}{l}\text { Kageyama et al., 2018; } \\
\text { Kettles et al., } 2014\end{array}$ \\
\hline $\begin{array}{l}\text { Bacillariophyta/Coscinodisc } \\
\text { ophyceae/Melosiraceae }\end{array}$ & Melosira numuloides & Unknown & Unknown & 264 & N.T. & Keller et al., 1989 \\
\hline $\begin{array}{l}\text { Dinophyta/Dinophyceae/Sy } \\
\text { mbiodiniaceae }\end{array}$ & $\begin{array}{l}\text { Symbiodinium } \\
\text { microadriaticum CCMP } 2467\end{array}$ & Transamination & $\begin{array}{l}\text { DSYB; MTHB } \\
\text { methyltransferase }\end{array}$ & $282 \pm 35.0$ & N.T. & Curson et al., 2018 \\
\hline $\begin{array}{l}\text { Dinophyta/Dinophyceae/Cry } \\
\text { pthecodiniaceae }\end{array}$ & $\begin{array}{l}\text { Crypthecodinium cohnii } \\
\text { ATCC e } 32001\end{array}$ & Decarboxylation & $\begin{array}{l}\text { Unknown; L-Met } \\
\text { decarboxylase }\end{array}$ & N.T. & $\begin{array}{l}10^{2}-10^{3} \mu \mathrm{g} / \mathrm{L} \\
\text { culture }\end{array}$ & $\begin{array}{l}\text { Uchida et al., } 1993 \text { \& } \\
\text { 1996; Kitaguchi et al., } \\
2008\end{array}$ \\
\hline $\begin{array}{l}\text { Dinophyta/Dinophyceae/Gy } \\
\text { mnodiniaceae }\end{array}$ & Gymnodinium nelsonii & Unknown & Unknown & 280 & N.T. & $\begin{array}{l}\text { Dacey and Wakeham, } \\
1986\end{array}$ \\
\hline $\begin{array}{l}\text { Dinophyta/Dinophyceae/Pror } \\
\text { ocentraceae }\end{array}$ & Prorocentrum sp. IIB2b1 & Unknown & Unknown & 1,082 & N.T. & Curson et al., 2018 \\
\hline $\begin{array}{l}\text { Chlorophyta/Chlorophyceae/ } \\
\text { Volvocaceae }\end{array}$ & Platymonas subcordiformis & Unknown & Unknown & 170 & N.T. & Dickson and Kirst, 1986 \\
\hline \multirow[t]{2}{*}{$\begin{array}{l}\text { Chlorophyta/Ulvophyceae/U } \\
\text { lvaceae }\end{array}$} & Ulva lactuca & Unknown & Unknown & N.T. & $\begin{array}{l}23-128 \\
\mathrm{mmol} / \mathrm{g} \text { fresh } \\
\text { mass }\end{array}$ & $\begin{array}{l}\text { Greene, 1962; Reed, } \\
\text { 1983; Van Alstyne et al., } \\
2007\end{array}$ \\
\hline & Ulva intestinalis & Transamination & $\begin{array}{l}\text { Unknown; D- } \\
\text { MTHB } S \text { - } \\
\text { Methyltransferase }\end{array}$ & N.T. & $\begin{array}{l}7-34 \mathrm{mmol} / \mathrm{g} \\
\text { fresh mass }\end{array}$ & $\begin{array}{l}\text { Gage et al., 1997; Reed, } \\
\text { 1983; Van Alstyne et al., } \\
\text { 2001; Summers et al., } \\
\text { 1998 }\end{array}$ \\
\hline
\end{tabular}




\begin{tabular}{|c|c|c|c|c|c|c|}
\hline & Ulva pertusa & Transamination & $\begin{array}{l}\text { Unknown; MTHB } \\
S \text { - } \\
\text { methyltransferase }\end{array}$ & N.T. & $\begin{array}{l}\sim 12-37 \\
\mu \mathrm{mol} / \mathrm{g} \text { fresh } \\
\text { mass }\end{array}$ & Ito et al., 2011 \\
\hline $\begin{array}{l}\text { Rhodophyta/Florideophycea } \\
\text { e/Hypneaceae }\end{array}$ & Hypnea spinella & Unknown & Unknown & N.T. & $\begin{array}{l}0.02-0.2 \\
\mathrm{mmol} / \mathrm{g} \text { fresh } \\
\text { mass }\end{array}$ & Bischoff et al., 1994 \\
\hline \multirow[t]{5}{*}{$\begin{array}{l}\text { Rhodophyta/Florideophycea } \\
\text { e/Rhodomelaceae }\end{array}$} & $\begin{array}{l}\text { Polysiphonia fastigiata \& } \\
\text { Polysiphonia nigrescens }\end{array}$ & Unknown & Unknown & N.T. & N.T. & $\begin{array}{l}\text { Challenger and Simpson, } \\
1948\end{array}$ \\
\hline & Polysiphonia hendryi & Unknown & Unknown & N.T. & $\begin{array}{l}8-30 \mathrm{mmol} / \mathrm{g} \\
\text { fresh mass }\end{array}$ & Van Alstyne et al., 2001 \\
\hline & Polysiphonia lanosa & Unknown & Unknown & N.T. & $\begin{array}{l}45-97 \\
\mathrm{mmol} / \mathrm{g} \text { fresh } \\
\text { mass }\end{array}$ & Reed, 1983 \\
\hline & Rhodomela confervoides & Unknown & Unknown & N.T. & $\begin{array}{l}4-8 \mathrm{mmol} / \mathrm{g} \\
\text { fresh mass }\end{array}$ & Reed, 1983 \\
\hline & Chondria coerulescens & Unknown & Unknown & N.T. & N.T. & Chillemi et al., 1990 \\
\hline \multirow[t]{2}{*}{$\begin{array}{l}\text { Streptophyta/Liliopsida/Poac } \\
\text { eae }\end{array}$} & Spartina alterniflora & Methylation & $\begin{array}{l}\text { Unknown; L-Met } \\
\text { methyltransferase }\end{array}$ & N.T. & $\begin{array}{l}29.0 \mu \mathrm{mol} / \mathrm{g} \\
\text { fresh mass }\end{array}$ & Kocsis et al., 1998 \\
\hline & Saccharum spp. (sugarcane) & Unknown & Unknown & N.T. & $\begin{array}{l}6 \mu \mathrm{mol} / \mathrm{g} \\
\text { fresh mass }\end{array}$ & Paquet et al., 1994 \\
\hline Streptophyta/-/Asteraceae & Wollastonia biflora & Methylation & $\begin{array}{l}\text { Unknown; L-Met } \\
\text { methyltransferase }\end{array}$ & N.T. & $\begin{array}{l}\sim 12-30 \\
\mu \mathrm{mol} / \mathrm{g} \text { fresh } \\
\text { mass }\end{array}$ & $\begin{array}{l}\text { Hanson et al., 1994; } \\
\text { James et al., } 1995\end{array}$ \\
\hline $\begin{array}{l}\text { Cnidaria/Anthozoa/Acropori } \\
\text { dae }\end{array}$ & Acropora cervicornis & Transamination & $\begin{array}{l}\text { DSYB; MTHB } \\
\text { methyltransferase }\end{array}$ & N.T. & N.T. & Curson et al., 2018 \\
\hline
\end{tabular}




\begin{tabular}{lllll} 
Acropora millepora & Transamination & Unknown & N.T. & $\begin{array}{l}\sim 2.5-5.2 \\
\mathrm{nmol}^{2} \mathrm{~mm}^{2}\end{array}$ \\
Acropora tenuis & Transamination & Unknown & N.T. & $\begin{array}{l}\sim 3.1-6.0 \\
\mathrm{nmol}^{2} \mathrm{~mm}^{2}\end{array}$ \\
\hline
\end{tabular}

\begin{tabular}{|c|c|c|c|c|c|c|}
\hline \multicolumn{7}{|l|}{ BACTERIA (PROKARYOTE) } \\
\hline \multirow{11}{*}{$\begin{array}{l}\text { Proteobacteria/Alphaproteob } \\
\text { acteria/Rhodobacteraceae }\end{array}$} & Pseduooceanicola batsensis & Transamination & DsyB; MTHB & 6.3 & $40.5 \pm 0.2$ & Curson et al, 2017 \\
\hline & HTCC2597 & & methyltransferase & & $\begin{array}{l}\mathrm{pmol} / \mu \mathrm{g} \\
\text { protein }\end{array}$ & \\
\hline & Pelagibaca bermudensis & Transamination & DsyB; MTHB & 40.6 & $259 \pm 52.7$ & Curson et al, 2017 \\
\hline & HTCC2601 & & methyltransferase & & $\mathrm{pmol} / \mu \mathrm{g}$ & \\
\hline & & & & & protein & \\
\hline & Sediminimonas qiaohouensis & Transamination & DsyB; MTHB & 19.1 & $122 \pm 4.6$ & Curson et al, 2017 \\
\hline & DSM21189 & & methyltransferase & & $\mathrm{pmol} / \mu \mathrm{g}$ & \\
\hline & & & & & protein & \\
\hline & Sagittula stellata E-37 & Transamination & DsyB; MTHB & 1.7 & $11.1 \pm 0.3$ & Curson et al, 2017 \\
\hline & & & methyltransferase & & $\mathrm{pmol} / \mu \mathrm{g}$ & \\
\hline & & & & & protein & \\
\hline \multirow{6}{*}{$\begin{array}{l}\text { Proteobacteria/Alphaproteob } \\
\text { acteria/Stappia_f }\end{array}$} & Labrenzia aggregata & Transamination & DsyB; MTHB & 9.6 & $99.8 \pm 1.2$ & Curson et al, 2017 \\
\hline & LZB033 & & methyltransferase & & $\mathrm{pmol} / \mu \mathrm{g}$ & \\
\hline & & & & & protein & \\
\hline & Labrenzia aggregata IAM & Transamination & DsyB; MTHB & 5.1 & $32.9 \pm 2.7$ & Curson et al, 2017 \\
\hline & 12614 & & methyltransferase & & $\mathrm{pmol} / \mu \mathrm{g}$ & \\
\hline & & & & & protein & \\
\hline \multirow{3}{*}{$\begin{array}{l}\text { Proteobacteria/Alphaproteob } \\
\text { acteria/Rhodobiaceae }\end{array}$} & Amorphus coralli & Transamination & DsyB; MTHB & 1.3 & $8.2 \pm 0.2$ & Curson et al, 2017 \\
\hline & DSM19760 & & methyltransferase & & $\mathrm{pmol} / \mu \mathrm{g}$ & \\
\hline & & & & & protein & \\
\hline
\end{tabular}


Proteobacteria/Alphaproteob acteria/Rhodospirillaceae
Thalassobaculum salexigens DSM19539
Transamination

DsyB; MTHB

methyltransferase
$4.8 \pm 1.6$

$\mathrm{pmol} / \mu \mathrm{g}$

protein
Curson et al, 2017

*Values that were taken from the literature with various incubation conditions and culturing media. \# Per liter of cell volume. N.T., not tested. 
Table 3 Major representative DMSP-degrading biological taxa

\begin{tabular}{|c|c|c|c|c|c|c|}
\hline $\begin{array}{l}\text { Taxonomic position } \\
\text { (phylum/class/family) }\end{array}$ & Strain & $\begin{array}{l}\text { Degradati } \\
\text { on enzyme }\end{array}$ & $\begin{array}{l}\text { DMSP breakdown } \\
\text { product }\end{array}$ & Polypeptide class & $\begin{array}{l}\text { Crystallization, co- } \\
\text { factor and key amino } \\
\text { acid residue }\end{array}$ & Reference \\
\hline \multicolumn{7}{|c|}{ BACTERIA (PROKARYOTE) } \\
\hline \multirow{15}{*}{$\begin{array}{l}\text { Proteobacteria/Alphaproteob } \\
\text { acteria/Rhodobacteraceae }\end{array}$} & Roseobacter sp. MED193 & DddW & DMS and acrylate & cupin superfamily & no & Todd et al., 2012a \\
\hline & \multirow[t]{5}{*}{ Ruegeria pomeroyi DSS-3 } & DddW & DMS and acrylate & cupin superfamily & no & $\begin{array}{l}\text { Todd et al., 2012a } \\
\text { Brummett et al., } 2015\end{array}$ \\
\hline & & DddQ & DMS and acrylate & cupin superfamily & no & Todd et al., 2011 \\
\hline & & DddP & DMS and acrylate & $\begin{array}{l}\text { M24B metallopeptidase } \\
\text { family (COG0006) }\end{array}$ & no & Curson et al., 2011a \\
\hline & & \multirow[t]{2}{*}{ DmdA } & MMPA & Glycine cleavage system & \multirow[t]{2}{*}{ no } & \multirow[t]{2}{*}{ Reisch et al., 2008} \\
\hline & & & $\begin{array}{l}\mathrm{X}-\mathrm{CH}_{3} \text { (in which } \mathrm{X} \\
\text { is tetrahydrofolate) }\end{array}$ & T family (COG0404) & & \\
\hline & \multirow{2}{*}{$\begin{array}{l}\text { Ruegeria lacuscaerulensis } \\
\text { ITI_1157 }\end{array}$} & \multirow[t]{2}{*}{ DddQ } & \multirow[t]{2}{*}{ DMS and acrylate } & \multirow{2}{*}{ cupin superfamily } & \multirow{2}{*}{$\begin{array}{l}\text { yes, } \mathrm{Zn}^{2+}, \text { Tyr131 or } \\
\mathrm{Fe}^{3+}, \text { Tyr120 }\end{array}$} & \multirow{2}{*}{$\begin{array}{l}\text { Li et al., } 2014 \\
\text { Curson et al., 2011b; } \\
\text { Brummett et al., } 2016\end{array}$} \\
\hline & & & & & & \\
\hline & Roseobacter denitrificans & DddP & DMS and acrylate & $\begin{array}{l}\text { M24B metallopeptidase } \\
\text { family (COG0006) }\end{array}$ & yes, $\mathrm{Fe}^{3+}$ & Hehemann et al., 2014 \\
\hline & Ruegeria lacuscaerulensis & DddP & DMS and acrylate & $\begin{array}{l}\text { M24B metallopeptidase } \\
\text { family (COG0006) }\end{array}$ & yes, $\mathrm{Zn}^{2+}$, & Wang et al., 2015 \\
\hline & Roseovarius nubinhibens & DddQ & DMS and acrylate & cupin superfamily & no & Kirkwood et al., 2010 \\
\hline & ISM & DddP & DMS and acrylate & $\begin{array}{l}\text { M24B metallopeptidase } \\
\text { family (COG0006) }\end{array}$ & no & Todd et al., 2009 \\
\hline & Sagittula stellata E-37 & DddD & DMS and $3 \mathrm{HP}$ & $\begin{array}{l}\text { Class III CoA transferase } \\
\text { family (COG1804) }\end{array}$ & no & Curson et al., 2011a \\
\hline & $\begin{array}{l}\text { Dinoroseobacter shibae } \\
\text { DFL } 12\end{array}$ & DddL & DMS and acrylate & cupin superfamily & no & Curson et al., $2011 \mathrm{a}$ \\
\hline & Sulfitobacter sp. EE-36 & DddL & DMS and acrylate & cupin superfamily & no & Curson et al., 2011a \\
\hline $\begin{array}{l}\text { Proteobacteria/Alphaproteob } \\
\text { acteria/Alcaligenaceae }\end{array}$ & Alcaligenes faecalis M3A & DddY & DMS and acrylate & cupin superfamily & no & Curson et al., 2011b \\
\hline $\begin{array}{l}\text { Proteobacteria/Alphaproteob } \\
\text { acteria/Rhizobiaceae }\end{array}$ & Rhizobium NGR234 & DddD & DMS and 3HP & $\begin{array}{l}\text { Class III CoA transferase } \\
\text { family (COG1804) }\end{array}$ & no & Todd et al., 2007 \\
\hline
\end{tabular}




\begin{tabular}{|c|c|c|c|c|c|c|}
\hline \multirow[t]{2}{*}{$\begin{array}{l}\text { Proteobacteria/Alphaproteob } \\
\text { acteria/Pelagibacteraceae }\end{array}$} & Pelagibacter ubique & DmdA & $\begin{array}{l}\text { MMPA plus } \\
\mathrm{X}-\mathrm{CH}_{3} \text { (in which } \mathrm{X} \\
\text { is tetrahydrofolate) }\end{array}$ & $\begin{array}{l}\text { Glycine cleavage system } \\
\mathrm{T} \text { family (COG0404) }\end{array}$ & $\begin{array}{l}\text { yes, THF used as } \\
\text { methyl acceptor }\end{array}$ & Reisch et al., 2008 \\
\hline & & DddK & DMS and 3HP & cupin superfamily & yes, $\mathrm{Fe}^{2+} \mathrm{Zn}^{2+}$, Tyr64 & Schnicker et al., 2017 \\
\hline $\begin{array}{l}\text { Proteobacteria/Gammaproteo } \\
\text { bacteria/Oceanospirillaceae }\end{array}$ & Marinomonas MWYL1 & DddD & DMS and 3HP & $\begin{array}{l}\text { Class III CoA transferase } \\
\text { family (COG1804) }\end{array}$ & no & Todd et al., 2007 \\
\hline $\begin{array}{l}\text { Proteobacteria/Gammaproteo } \\
\text { bacteria/Moraxellaceae }\end{array}$ & Acinetobacter bereziniae & DddY & DMS and acrylate & cupin superfamily & yes, $\mathrm{Zn}^{2+}$, Tyr271 & Li et al., 2017 \\
\hline $\begin{array}{l}\text { Proteobacteria/Gammaproteo } \\
\text { bacteria/Shewanellaceae }\end{array}$ & $\begin{array}{l}\text { Shewanella putrefaciens } \\
\text { CN-32 }\end{array}$ & DddY & DMS and acrylate & cupin superfamily & no & $\begin{array}{l}\text { Curson et al., 2011b; Lei } \\
\text { et al., } 2018\end{array}$ \\
\hline $\begin{array}{l}\text { Proteobacteria/Gammaproteo } \\
\text { bacteria/Halomonadaceae }\end{array}$ & Halomonas HTNK1 & DddD & DMS and 3HP & $\begin{array}{l}\text { Class III CoA transferase } \\
\text { family }\end{array}$ & no & Todd et al., 2010 \\
\hline $\begin{array}{l}\text { Proteobacteria/Betaproteoba } \\
\text { cteria/Burkholderiaceae }\end{array}$ & $\begin{array}{l}\text { Burkholderia } \\
\text { AMMD }\end{array}$ & DddD & DMS and $3 \mathrm{HP}$ & $\begin{array}{l}\text { Class III CoA transferase } \\
\text { family (COG1804) }\end{array}$ & no & Todd et al., 2007 \\
\hline $\begin{array}{l}\text { Proteobacteria/Epsilonproteo } \\
\text { bacteria/Campylobacteraceae }\end{array}$ & $\begin{array}{l}\text { Arcobacter } \quad \text { nitrofigilis } \\
\text { DSM7299 }\end{array}$ & DddY & DMS and acrylate & cupin superfamily & no & Curson et al., 2011b \\
\hline $\begin{array}{l}\text { Proteobacteria/Deltaproteoba } \\
\text { cteria/Desulfovibrionaceae }\end{array}$ & Desulfovibrio acrylicus sp. & DddY & DMS and acrylate & cupin superfamily & no & $\begin{array}{l}\text { Van der Maarel and } \\
\text { Hansen, 1996; Curson et } \\
\text { al., 2011b }\end{array}$ \\
\hline $\begin{array}{l}\text { Actinobacteria/Actinobacteri } \\
\text { a/Nocardiaceae }\end{array}$ & $\begin{array}{l}\text { Rhodococcus sp. DY1, } \\
\text { DY5, DY6, DY7 \& DY8 }\end{array}$ & Unknown & $\begin{array}{l}\text { DMS } \\
\text { acrylate/3HP }\end{array}$ & N.A. & N.A. & Yoch et al., 2001 \\
\hline $\begin{array}{l}\text { Firmicutes/Clostridia/Clostri } \\
\text { diaceae }\end{array}$ & Clostridium sp. & Unknown & DMS and acrylate & N.A. & N.A. & $\begin{array}{l}\text { Wagner and Stadtman, } \\
1962\end{array}$ \\
\hline \multicolumn{7}{|c|}{ ALGAE \& FUNGI (EUKARYOTE) } \\
\hline $\begin{array}{l}\text { Ascomycota/Eurotiomycetes } \\
\text { /Trichocomaceae }\end{array}$ & Aspergillus oryzae RIB40 & DddP & DMS and acrylate & $\begin{array}{l}\text { M24B metallopeptidase } \\
\text { family (COG0006) }\end{array}$ & no & Todd et al., 2009 \\
\hline \multirow[t]{2}{*}{$\begin{array}{l}\text { Ascomycota/Sordariomycete } \\
\text { s /Nectriaceae }\end{array}$} & $\begin{array}{l}\text { Fusarium graminearum } \\
\text { cc19 }\end{array}$ & DddP & DMS and acrylate & $\begin{array}{l}\text { M24B metallopeptidase } \\
\text { family (COG0006) }\end{array}$ & no & Todd et al., 2009 \\
\hline & Fusarium culmorum Fu42 & DddP & DMS and acrylate & $\begin{array}{l}\text { M24B metallopeptidase } \\
\text { family (COG0006) }\end{array}$ & no & Todd et al., 2009 \\
\hline $\begin{array}{l}\text { Haptophyta/Prymnesiophyce } \\
\text { ae/Noelaerhabdaceae }\end{array}$ & Emiliania huxleyi HL373 & Alma 1 & DMS and acrylate & $\begin{array}{l}\text { aspartate } \\
\text { superfamily }\end{array}$ & no & Alcolombri et al., 2015 \\
\hline
\end{tabular}




\begin{tabular}{|c|c|c|c|c|c|c|c|}
\hline & E. huxleyi BT6 & Unknown & DMS and acrylate & N.A. & & N.A. & Yoch, 2002 \\
\hline $\begin{array}{l}\text { Haptophyta/Prymnesiophyce } \\
\text { ae/Phaeocystaceae }\end{array}$ & Phaeocystis sp. & Unknown & DMS and acrylate & N.A. & & N.A. & Stefels et al., 1995 \\
\hline \multirow[t]{2}{*}{$\begin{array}{l}\text { Alveolata/Dinophyceae/Sym } \\
\text { biodiniaceae }\end{array}$} & \multirow{2}{*}{$\begin{array}{l}\text { Symbiodinium } \\
\text { microadriaticum; } \\
\text { Symbiodinium sp. }\end{array}$} & Unknown & DMS and acrylate & N.A. & & N.A. & $\begin{array}{l}\text { Yost and Mitchelmore, } \\
2009\end{array}$ \\
\hline & & Alma1 & DMS and acrylate & $\begin{array}{l}\text { aspartate } \\
\text { superfamily }\end{array}$ & racemase & no & Alcolombri et al., 2015 \\
\hline $\begin{array}{l}\text { Alveolata/Dinophyceae/Thor } \\
\text { acosphaeraceae }\end{array}$ & Scrippsiella spp. & Unknown & DMS and acrylate & N.A. & & N.A. & Niki et al., 1997 \\
\hline $\begin{array}{l}\text { Alveolata/Dinophyceae/Hete } \\
\text { rocapsa }\end{array}$ & $\begin{array}{l}\text { Heterocapsa } \\
\text { NIES-7 }\end{array}$ & Unknown & DMS and acrylate & N.A. & & N.A. & Niki et al., 2000 \\
\hline $\begin{array}{l}\text { Chlorophyta/Ulvophyceae/U } \\
\text { lvaceae }\end{array}$ & Ulva lactuca & Unknown & DMS and acrylate & N.A. & & N.A. & Diaz et al. 1994 \\
\hline \multirow[t]{2}{*}{$\begin{array}{l}\text { Rhodophyta/Florideophycea } \\
\text { e/Rhodomelaceae }\end{array}$} & Polysiphonia paniculata & Unknown & DMS & N.A. & & N.A. & $\begin{array}{l}\text { Nishiguchi and Goff, } \\
2010\end{array}$ \\
\hline & Polysiphonia lanosa & Unknown & DMS and acrylate & N.A. & & N.A. & $\begin{array}{l}\text { Anderson and Cantoni, } \\
1956\end{array}$ \\
\hline
\end{tabular}

N.A. not applicable; MMPA, methylmercaptopropionate. 
Table 4 Functions of DMSP and DMS

\begin{tabular}{|c|c|c|c|c|}
\hline Compounds & $\begin{array}{l}\text { Functional } \\
\text { types }\end{array}$ & Specific functions & Related organisms & References \\
\hline \multirow[t]{4}{*}{ DMSP } & $\begin{array}{l}\text { Physiological } \\
\text { functions }\end{array}$ & Osmoprotectant & $\begin{array}{l}\text { Poterioochromonas malhamensis (Synurophyceae); } \\
\text { Dunaliella spp. (Chlorophyceae); } \\
\text { Polysiphonia lanosa (Florideophyceae); } \\
\text { Blidingia minima (Ulvophyceae); } \\
\text { Ulva lactuca (Ulvophyceae); } \\
\text { some Rhodophyceae; } \\
\text { some Phaeophyceae }\end{array}$ & $\begin{array}{l}\text { Kirst, 1990; Vairavamurthy et } \\
\text { al., } 1985\end{array}$ \\
\hline & & Cryoprotectant & $\begin{array}{l}\text { Acrosiphonia arcta (Ulvophyceae); } \\
\text { Microcoleus chthonoplastes (Cyanobacteria); } \\
\text { Enteromorpha bulbosa (Ulvophyceae); } \\
\text { Ulothrix subflaecida (Klebsormidiophyceae) }\end{array}$ & Karsten et al., 1996 \\
\hline & & Antioxidant & $\begin{array}{l}\text { Phaeocystis sp. (Haptophyceae); } \\
\text { Emiliania huxleyi (Haptophyceae); } \\
\text { Prymnesium parvum (Haptophyceae); } \\
\text { Thalassiosira pseudonana (diatom); } \\
\text { Skeletonema costatum (diatom); } \\
\text { Pfiesteria piscicida (Dinophyceae) }\end{array}$ & $\begin{array}{l}\text { Sunda et al., 2002; Lesser, } \\
\text { 2006; Husband et al., 2012; } \\
\text { Curson et al., } 2018\end{array}$ \\
\hline & & $\begin{array}{l}\text { Sink of excess sulfur, carbon and } \\
\text { reduced equivalent }\end{array}$ & $\begin{array}{l}\text { photosynthetic marine algae and higher plants } \\
\text { e.g. Enteromorpha intestinalis (Ulvophyceae) }\end{array}$ & $\begin{array}{l}\text { Gage et al., 1997; Stefels } \\
\text { 2000; Bullock et al., } 2017\end{array}$ \\
\hline
\end{tabular}


Saving nitrogen for cell growth and accelerating sulfate uptake from the environment

$\begin{array}{lll}\text { Biological Resolving the damage of thermal Acropora millepora and Acropora tenuis (coral); } & \text { Raina et al., } 2013 \\ \text { functions } & \text { stress and signal molecule attracting }\end{array}$
certain beneficial bacteria for coral

\section{Predator deterrent}

Mediator of bacterial virulence associated with regulation of $E$ huxleyi blooms

Bacterial quorum sensing inducer, related to decomposition of particulate organic matter (POC)
Chemoattractant

\section{Emiliania huxleyi (Haptophyceae)}

Emiliania huxleyi (Haptophyceae);

Sulfitobacter (Alphaproteobacteria);

Pseudoalteromonas piscicida (Gammaproteobacteria)

Silicibacter sp.(Alphaproteobacteria);

reef fishes

Ruegeria pomeroyi DSS-3 (Alphaproteobacteria)

N.A.

Ecological The main precursor of DMS

functions

(1)

\section{Wolfe and Steinke, 1996}

Barak-Gavish et al., 2018

Miller et al., 2004; Seymour et al., 2010; DeBose et al., 2008

Seyedsayamdost et al., 2011; Johnson et al., 2016 
Biogeochemical cycle of sulfur and N.A.

Curson et al., 2011a

carbon in the ocean

\begin{tabular}{|c|c|c|c|c|}
\hline \multirow[t]{5}{*}{ DMS } & $\begin{array}{l}\text { Biological } \\
\text { function }\end{array}$ & Chemoattractant & $\begin{array}{l}\text { Diomedea exulans and Pachyptila desolata (Aves); } \\
\text { fish over coral reefs; } \\
\text { calanoid and Temora longicornis (copepod); } \\
\text { Flagellates and ciliates; }\end{array}$ & $\begin{array}{l}\text { Steinke et al., 2006; DeBose } \\
\text { and Nevitt, 2008; Nevitt, } 2008\end{array}$ \\
\hline & & Antioxidant & $\begin{array}{l}\text { Emiliania huxleyi (Haptophyceae) } \\
\text { Phaeocystis sp. (Haptophyceae) } \\
\text { Skeletonema costatum (Coscinodiscophyceae) }\end{array}$ & $\begin{array}{l}\text { Sunda et al., 2002; Lesser, } \\
2006\end{array}$ \\
\hline & $\begin{array}{l}\text { Ecological } \\
\text { functions }\end{array}$ & $\begin{array}{l}\text { Climate-cooling gas, which is the } \\
\text { precursor of sulfuric cloud } \\
\text { condensation nuclei (CCN), } \\
\text { increasing cloud formation and then } \\
\text { the albedo of the earth }\end{array}$ & N.A. & $\begin{array}{l}\text { Charlson et al., 1987; Ayers } \\
\text { and Gras, 1991; Andreae and } \\
\text { Crutzen, } 1997\end{array}$ \\
\hline & & $\begin{array}{l}\text { The greatest flux of organosulfur } \\
\text { from the ocean into the atmosphere }\end{array}$ & N.A. & $\begin{array}{l}\text { Lovelock et al., 1972; Chin } \\
\text { and Jacob 1996; Kettle and } \\
\text { Andreae, } 2000\end{array}$ \\
\hline & & $\begin{array}{l}\text { Ease the stratification of seawater and } \\
\text { form a positive feedback loop }\end{array}$ & N.A. & Lovelock, 2006 \\
\hline
\end{tabular}

N.A. not applicable. 


\section{Figure legends}

Figure 1 The fate of dimethylsulfoniopropionate (DMSP) and dimethylsulfide (DMS). 3HP, 3-hydroxypropionate; CCN, cloud condensation nuclei; DMSO, dimethyl sulfoxide; MeSH, methanethiol; MMPA, methylmercaptopropionate; TCA, tricarboxylic acid; X, tetrahydrofolate.

Figure 2 Green tide outbreak in the beach of Qingdao, China in July 2018.

Figure 3 Predicted pathways for DMSP biosynthesis in higher plants, coral, phytoplankton and bacteria (modified from Curson et al., 2017). Wollastonia (a), Spartina and bacteria (Streptomyces) (b); macroalgae (Ulva, Enteromorpha), diatoms (Thalassiosira, Melosira), prymnesiophyte (Emiliania), prasinophyte (Tetraselmis), coral (Acropora) and bacterium (Labrenzia) (c) and dinoflagellate (Crypthecodinium) (d).

Abbreviations: Met, methionine; AdoMet, S-adenosylmethionine; AdoHcy, S-adenosyl-L-homocysteine; DMSP-ald., DMSP-aldehyde; MMPA, methylmercaptopropionate.

Figure 4 Morphology of the model DMSP and DMS-producing bacterial strain Labrenzia aggregata LZB033. (A) Plate streaking of LZB033. (B) Fluorescence microscopy of LZB033 cells stained with DAPI. (C) Transmission electron microscopy of one LZB033 cell acquired from Marine

Broth culture, scale bar $=1 \mu \mathrm{m}$. (D) Transmission electron microscopy of transections and a longitudinal section of LZB033 cells processed by ultramicrotomy, scale bar $=500 \mathrm{~nm}$. 